\title{
Demonstration of a Rapid HPLC-ICPMS Direct Coupling Technique Using IDMS-Project Report: Part II
}

\section{Approved for public release.} Distribution is unlimited.
Benjamin D. Roach David C. Glasgow Emilie K. Fenske Ralph H. Ilgner Cole R. Hexel Joseph M. Giaquinto

October 2017 


\section{DOCUMENT AVAILABILITY}

Reports produced after January 1, 1996, are generally available free via US Department of Energy (DOE) SciTech Connect.

Website http://www.osti.gov/scitech/

Reports produced before January 1, 1996, may be purchased by members of the public from the following source:

National Technical Information Service

5285 Port Royal Road

Springfield, VA 22161

Telephone 703-605-6000 (1-800-553-6847)

TDD 703-487-4639

Fax 703-605-6900

E-mail info@ntis.gov

Website http://classic.ntis.gov/

Reports are available to DOE employees, DOE contractors, Energy Technology Data Exchange representatives, and International Nuclear Information System representatives from the following source:

Office of Scientific and Technical Information

PO Box 62

Oak Ridge, TN 37831

Telephone 865-576-8401

Fax 865-576-5728

E-mail reports@osti.gov

Website http://www.osti.gov/contact.html

This report was prepared as an account of work sponsored by an
agency of the United States Government. Neither the United States
Government nor any agency thereof, nor any of their employees, makes
any warranty, express or implied, or assumes any legal liability or
responsibility for the accuracy, completeness, or usefulness of any
information, apparatus, product, or process disclosed, or represents that
its use would not infringe privately owned rights. Reference herein to
any specific commercial product, process, or service by trade name,
trademark, manufacturer, or otherwise, does not necessarily constitute
or imply its endorsement, recommendation, or favoring by the United
States Government or any agency thereof. The views and opinions of
authors expressed herein do not necessarily state or reflect those of the
United States Government or any agency thereof. 
Chemical Sciences Division

Nuclear Analytical Chemical and Isotopics Laboratory

\title{
DEMONSTRATION OF A RAPID HPLC-ICPMS DIRECT COUPLING TECHNIQUE USING IDMS-PROJECT REPORT: PART II
}

\author{
Benjamin D. Roach \\ David C. Glasgow \\ Emilie Fenske \\ Ralph H. Ilgner \\ Cole R. Hexel \\ Joseph M. Giaquinto
}

Date Published: October 2017

Prepared by

OAK RIDGE NATIONAL LABORATORY

Oak Ridge, TN 37831-6283

managed by

UT-BATTELLE, LLC

for the

US DEPARTMENT OF ENERGY

under contract DE-AC05-00OR22725 



\section{CONTENTS}

\section{LIST OF FIGURES}

LIST OF TABLES

EXECUTIVE SUMMARY

1. INTRODUCTION

1.1 SCOPE OF WORK

1.2 FACILITIES AND CAPABILITIES

2. EXPERIMENTAL

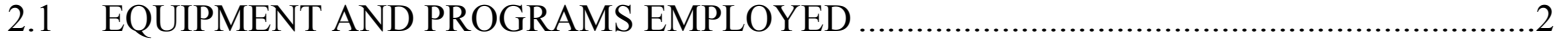

3. RESULTS

3

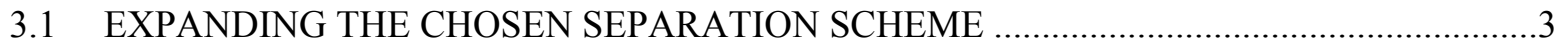

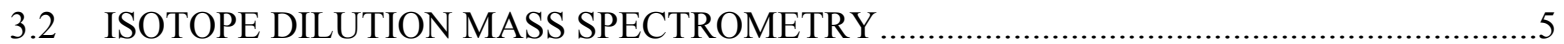

3.3 DESIGNING AND PRODUCING A SURROGATE MATRIX ….....................................6

3.3.1 Chromatograms Produced Using the Modified Separation Scheme in the

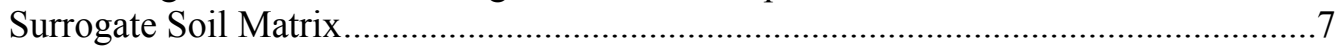

3.4 METHOD STABILITY AND REPRODUCIBILITY WITHIN SURROGATE SOIL

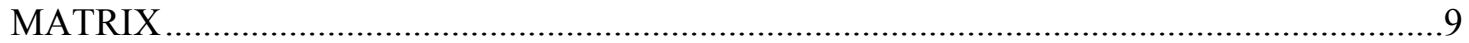

3.5 LIMITS OF DETECTION AND QUANTITATION IN SURROGATE SOIL MATRIX .......11

3.6 MEASURING FISSION PRODUCT RATIOS IN IRRADIATED HIGHLY

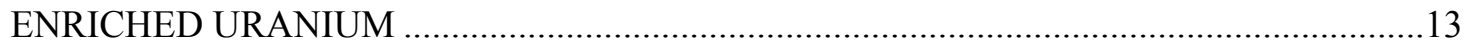

3.6.1 Irradiation of Highly Enriched Uranium at the HFIR Facility...................................13

3.6.2 Ampoule Opening, Dissolution, and ${ }^{235} \mathrm{U}$ Concentration Verification ..........................14

3.6.3 Fission Product Analysis of Irradiated HEU using Modified HPIC-ICPMS

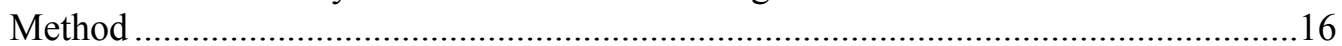

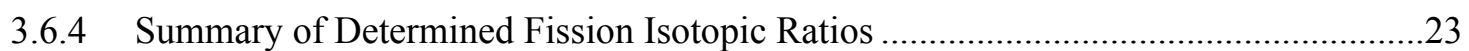

4. CONCLUSION

5. REFERENCES

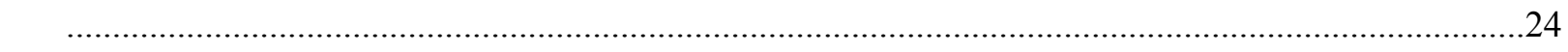

APPENDIX A. SEPARATION PROTOCOL FOR CHROMELEON PATCH IN QTEGRA ${ }^{\mathrm{TM}}$

APPENDIX B. PEAK DETECTION SETTINGS FOR QTEGRATM

APPENDIX C. ORIGEN CALCULATED FISSION FOR $80 \mu \mathrm{G}$ TARGET WITH 36.1 D DECAY

APPENDIX D. ORIGEN CALCULATED FISSION FOR $35 \mu \mathrm{G}$ TARGET WITH 36.1 D DECAY 


\section{LIST OF FIGURES}

Figure 1. Photo of the coupled HPIC-ICPMS system in a radiological fume hood.

Figure 2. Photo of remote handling cubicle (left), and a decay station in HFIR pool, drained

Figure 3. Gradient separation scheme using deionized water (yellow), 6 mM PDCA (green), 100

mM oxalic acid (pink), and 100 mM DGA (blue) .................................................................

Figure 4. Chromatograms for each of the neodymium isotopes for the natural IV-ICPMS-71A standard (left, $125 \mathrm{pg}$ injection) and the natural standard spiked with the ${ }^{150} \mathrm{Nd}$ enriched IDMS-023 spike (right, 125 pg injection).

Figure 5. Chromatogram illustrating 30 of the 49 elements monitored with the modified separation scheme.

Figure 6. Partial chromatogram $(t=1600-2000)$, displaying the elution of the lanthanide elements indicating retained resolution in the surrogate matrix.

Figure 7. Partial chromatogram of the transition metals $(\mathrm{t}=200-800)$.

Figure 8 . The $t=40-580$ region of the chromatogram illustrated in Figure 4 showing each of the

individual analytes in more detail, including isotopic sensitivity, peak shape, retention time, isobaric and elemental overlap, and peak tailing.

Figure 9. Graphical representation of the 49 elements, in which Bar americium and curium are completely separated from isobaric interferences.

Figure 10. ORIGEN calculation for the larger target $(80 \mu \mathrm{g})$ for a $48.5 \mathrm{~h}$ irradiation period, yielding approximately $1 \mathrm{E}+14$ fissions.

Figure 11. ORIGEN calculation for the larger target $(80 \mu \mathrm{g})$ for a $48.5 \mathrm{~h}$ irradiation period, yielding approximately $1 \mathrm{E}+14$ fissions.

Figure 12. A diagram of the PT-1 facility highlighting the sample transfer path and irradiation

site.

Figure 13. Photographs of the mini-vice used for opening targets (left panel) and micropipette tips and malleable leached PTFE vessel (right panel).

Figure 14. Partial chromatogram of $50 \mu \mathrm{L}$ of a $2 \times$ dilution of the leachate from Target 1.

Figure 15. Partial chromatogram of $50 \mu \mathrm{L}$ of a $2 \times$ dilution of the leachate from Target 2 (top) and Target 1 (bottom), showing clear separation of the 147 masses ${ }^{147} \mathrm{Nd},{ }^{147} \mathrm{Pm}$, and ${ }^{147} \mathrm{Sm} . \ldots \ldots \ldots \ldots . . .18$

Figure 16. Partial chromatogram of $50 \mu \mathrm{L}$ of a $2 \times$ dilution of the leachate from Target 1.

Figure 17. Partial chromatogram of $50 \mu \mathrm{L}$ of a $2 \times$ dilution of the leachate from Target 1.

Figure 18. The $\mathrm{m} / \mathrm{z} 149$ and $\mathrm{m} / \mathrm{z} 151$ chromatograms, showing clear separation between the ${ }^{151} \mathrm{Sm}$

$(\mathrm{t}=1875)$ and the contaminant ${ }^{151} \mathrm{Eu}$ isotope $(\mathrm{t}=1920) \ldots$

Figure 19. M/z 133, m/z 135, and m/z 137 chromatograms, showing clear separation between the naturally occurring barium isotopes ${ }^{135} \mathrm{Ba}$ and ${ }^{137} \mathrm{Ba}(\mathrm{t}=90)$ and cesium.

Figure 20. The m/z 101 and m/z 102 chromatograms for Target 1 showing the ${ }^{101} \mathrm{Ru}$ and ${ }^{102} \mathrm{Ru}$ peaks.

Figure 21. The $\mathrm{m} / \mathrm{z} 89$ and $\mathrm{m} / \mathrm{z} 90$ chromatograms for Target 1 showing the ${ }^{89} \mathrm{Sr}$ and ${ }^{90} \mathrm{Sr}$ peaks. 


\section{LIST OF TABLES}

Table 1. Timings and percent contribution from each eluent for the separation scheme detailed in Figure 1 .

Table 2. IDMS recovery numbers for a IV-ICPMS-71A (10 $\mu \mathrm{g} / \mathrm{mL}$ multielement standard), using the IDMS-023 enriched isotope mixed lanthanide standard.

Table 3. Elemental composition of surrogate NIST 2711a soil showing the compound used and the elemental weight fractions

Table 4. Microwave digestion settings as described in [5]

Table 5. Elemental retention times in the original method development study and the surrogate soil matrix, together with the observed RSD of the nine replicates over the $24 \mathrm{~h}$ period

Table 6. LODs and LOQs for the individual isotopes monitored both with and without a dissolved surrogate soil matrix

Table 7. Elemental elution times for various matrices

Table 8. The normalized natural abundance and ORIGEN predicted fission abundance of the neodymium isotopes ${ }^{144} \mathrm{Nd},{ }^{145} \mathrm{Nd},{ }^{146} \mathrm{Nd},{ }^{147} \mathrm{Nd},{ }^{148} \mathrm{Nd}$, and ${ }^{150} \mathrm{Nd}$, and the normalized isotopic abundances observed for each target

Table 9. The observed ${ }^{141} \mathrm{Ce}:{ }^{144} \mathrm{Ce}$ ratios for Targets 1 and 2 with the ORIGEN ratio calculated with a $36.1 \mathrm{~d}$ decay time postirradiation.

Table 10. Observed cesium isotopic compositions and ${ }^{135} \mathrm{Cs}:{ }^{137} \mathrm{Cs}$ ratios for Targets 1 and 2 compared with the ORIGEN ratio calculated with a $36.1 \mathrm{~d}$ decay time postirradiation

Table 11. Summary of measured isotopic ratios with their recovery from that calculated in ORIGEN 


\section{EXECUTIVE SUMMARY}

Researchers working on chemical separations and inductively coupled plasma mass spectrometry have developed a rapid separation-direct analysis scheme to determine both concentration and isotopics of a suite of elements down to the low picogram level, with the ultimate goal of performing rapid analysis of postdetonation nuclear materials. The second phase in method development has shown that both the sensitivity and stability to achieve the precise, low-level analyses required can be maintained even when present in complex silicon- and uranium-based matrices. The methods analyte list has been expanded to incorporate a number of new analytes, notably the actinides plutonium, americium, curium, neptunium, and thorium and the key fission product zirconium. Key nonnatural fission product isotopic ratios in irradiated highly enriched uranium targets have been successfully measured at the low picogram level. The accuracy of these ratios was confirmed using an isotopic depletion and decay modeling software to within 1-2\%. 


\section{INTRODUCTION}

\subsection{SCOPE OF WORK}

This report documents fiscal year (FY) 2017 research efforts by the Nuclear Analytical Chemical and Isotopics Laboratory's (NACIL's) Radioactive Material Analysis Laboratory (RMAL) nuclear analytical facility. The work discussed in this report shows that the predefined experimental strategies for the rapid measurement of isotopic and elemental concentrations in a multielement system can be applied to both complex matrices and the irradiation of nuclear materials. The work was divided into four stages: application of isotope dilution mass spectrometry (IDMS); expansion of the analyte list to include radioisotopes; determination of the stability and reproducibility of the developed chemistry in complex, silicon-based matrices; and determination of the successful application of the method to irradiated nuclear material. The data presented here shows the application of a successful method to overcome complex matrices while maintaining sensitivity and stability.

This work was undertaken to complete the "Demonstration of a Rapid HPLC-ICPMS Direct Coupling Technique Using IDMS Project T2" in response to Oak Ridge National Laboratory's (ORNL's) DTRA J9-NTFC/A FY 2015 solicitation "MIDAS 15-Technical and Analytical Support for the DTRA/J9 Nuclear Forensics Office." The description of this task is stated as:

Task:

Demonstrate the effectiveness of a rapid measurement protocol which directly couples High Pressure Liquid Chromatography (HPLC) and Inductively Coupled Plasma Mass Spectrometry (ICPMS). This technique would allow for rapid online HPLC chemical separations with direct isotopic detection and isotope ratio measurements using mass spectrometry and with the incorporation of IDMS improve accuracy and precision of the analyses over standard elemental and isotopic assay techniques.

The main goal of this research was to determine the feasibility of a single multieluent separation scheme that would enable the separation and analysis of as many of the predetermined analytes as possible in a complex matrix, such as glass, or in irradiated materials. ICPMS enables the analysis of isotopic masses and, together with elemental separation, is the ideal tool to measure nonnatural isotopes and isotopic ratios. The further development of the method was to ensure sufficient capability to achieve measurements of elemental and isotopic signatures at levels likely to be present in postdetonation material [1].

\subsection{FACILITIES AND CAPABILITIES}

The NACIL group possesses unique expertise in the analytical chemistry of the lanthanide and actinide elements as well as the preparation and separation chemistries required for analytical characterizations in a wide variety of nuclear sample matrices. The NACIL's unique laboratory capabilities allow for the handling of samples containing curie levels of radioactivity down to preparations requiring cleanroom spaces for ultratrace determinations. The group provides leadership for a number of US Department of Energy (DOE)-sponsoring agencies' analytical laboratory needs, working closely with those organizations to advance future technologies and analytical methods to support nuclear research, isotope production, and nonproliferation and safeguards. Funding sponsors for the group are primarily the DOE; National Nuclear Security Agency (NNSA); and various local, federal, and international agencies that sponsor research projects. For the final stages of method testing, the couple high pressure ion chromatography (HPIC)-ICPMS setup was moved into a radiological fume hood (see Figure 1) at RMAL, which enabled the receipt of irradiated material from the High Flux Isotope Reactor (HFIR). 

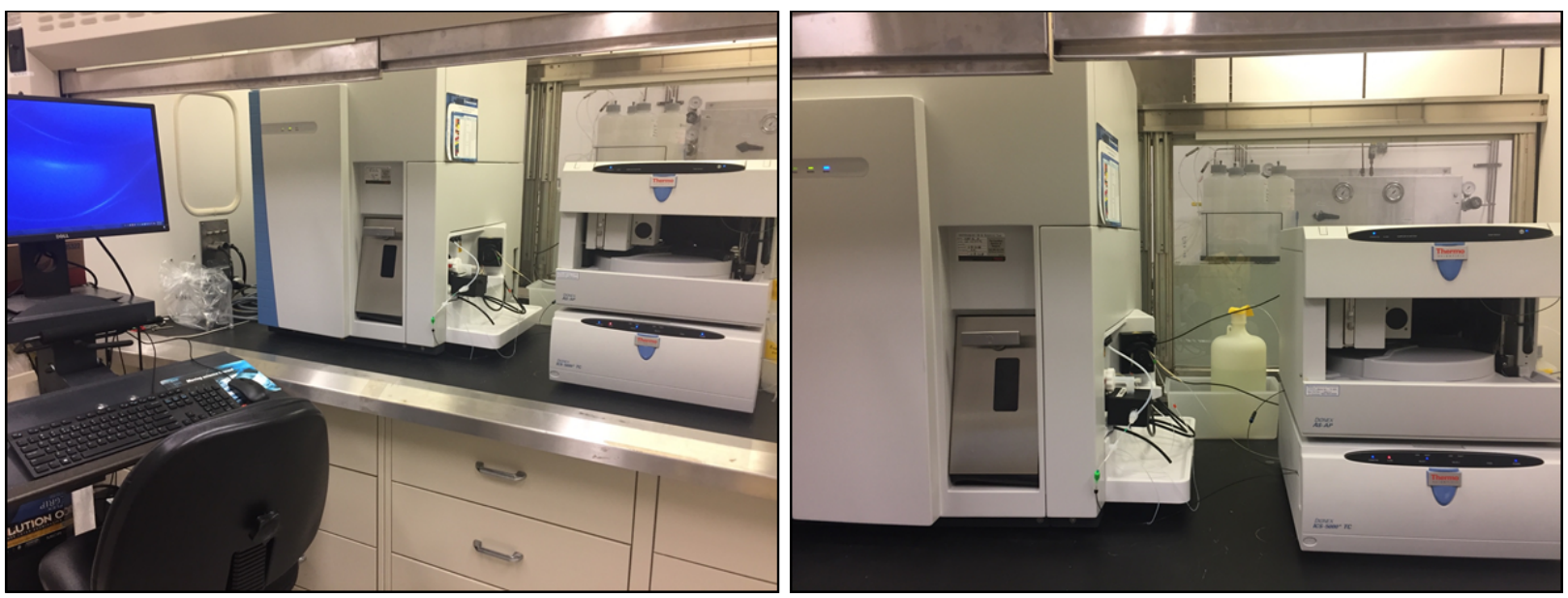

Figure 1. Photo of the coupled HPIC-ICPMS system in a radiological fume hood.

HFIR is a PT-1 irradiation facility with a flux of $4.3 \mathrm{E}+14 \mathrm{n} \mathrm{cm}^{-2} \mathrm{~s}^{-1}$ thermal, $1.1 \mathrm{E}+14 \mathrm{n} \mathrm{cm}^{-2} \mathrm{~s}^{-1}$ res., and $\sim 0.8 \mathrm{E}+13>0.1 \mathrm{MeV}$. Our capabilities include a remote-handling cubicle (Figure 2, left panel), and a decay station in HFIR pool (Figure 2, right panel). The MCNP model accurately reproduces the flux spectrum and enables accurate prediction of total fissions.
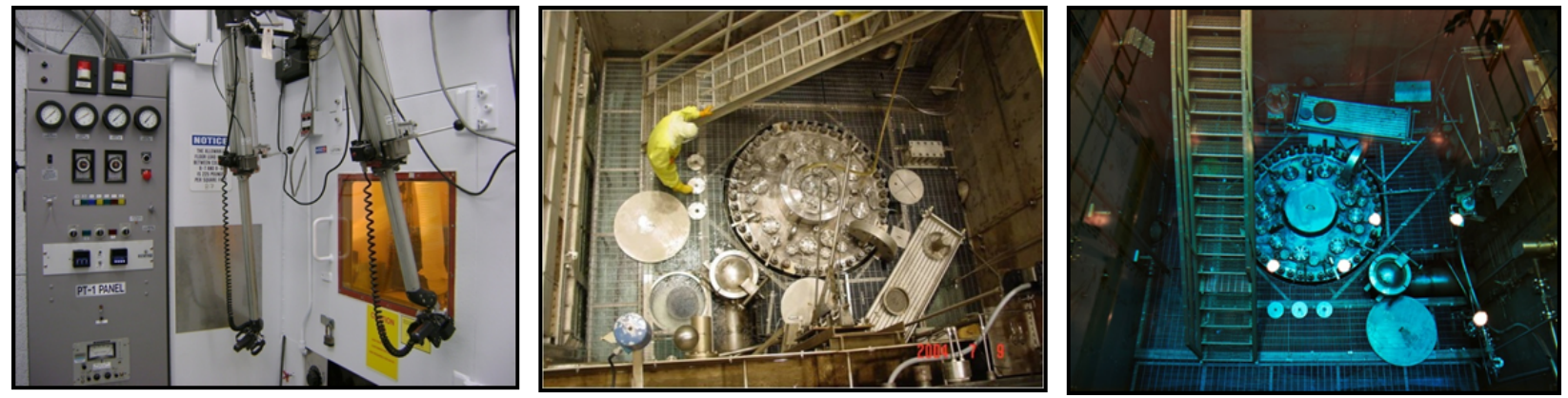

Figure 2. Photo of remote handling cubicle (left), and a decay station in HFIR pool, drained (center) and full (right).

\section{EXPERIMENTAL}

\subsection{EQUIPMENT AND PROGRAMS EMPLOYED}

A Thermo Scientific ${ }^{\mathrm{TM}}$ Dionex $^{\mathrm{TM}}$ ICS-5000+ HPIC system (Figure 1) coupled to a Thermo Scientific ${ }^{\mathrm{TM}}$

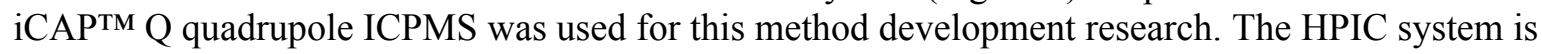
composed of an AS-AP autosampler having sample dilution and fraction collection capabilities; a gradient mixing pump capable of combining four different eluents in the same analysis; and a thermal compartment containing the injection loop and separation column, able to maintain temperatures of 5$85^{\circ} \mathrm{C}$ for constant elution times and reproducibility. The ICPMS is equipped with a wide-range sensitivity detector (from ppm to sub-ppt), a robust torch capable of withstanding the introduction of salts and organic matter from the HPIC eluents, a wide bore nebulizer that can nebulize solutions of higher density and organic content, and a specialized collision cell that reduces the signal-to-noise ratio for highprecision measurements of low-mass analytes.

The HPIC-ICPMS method employs Thermo Scientific ${ }^{\mathrm{TM}}$ Qtegra $^{\mathrm{TM}}$ Intelligent Scientific Data Solution ${ }^{\mathrm{TM}}$ (ISDS) platform software. This software provides integrated control and data processing for a range of 
elemental and isotopic analysis technologies including ICPMS and HPIC. Qtegra ${ }^{\mathrm{TM}}$ ISDS utilizes peripheral drivers from Thermo Scientific Chromeleon ${ }^{\mathrm{TM}}$ Chromatography Data System, enabling the simultaneous control of the ICPMS and HPIC. The Chromeleon ${ }^{\mathrm{TM}}$ script used for the developed separation scheme is detailed in Appendix A. The chromatographic peak smoothing and analysis values used within the peak detection settings of the Qtegra ${ }^{\mathrm{TM}}$ software can be found in Appendix B.

The SCALE code system [2], which was developed and is maintained by ORNL, is used internationally in support of spent nuclear fuel transportation and storage applications. SCALE includes an isotopic depletion and decay analysis module known as ORIGEN [3]. In this work the ORIGEN module in the SCALE code system is used to predict fission in two irradiated highly enriched uranium (HEU) targets.

\subsection{REAGENTS AND STANDARDS EMPLOYED}

Eluents for HPIC and all other solutions were prepared with trace metals basis-grade chemicals and ultrapure water $(18.2 \mathrm{M} \Omega \mathrm{cm})$ from a Millipore Milli- $\mathrm{Q}^{\mathrm{TM}}$ water purification system (Millipore). Chemicals for eluents including diglycolic acid (DGA) $\left(\mathrm{C}_{4} \mathrm{H}_{6} \mathrm{O}_{5}\right)$ (recrystallized) $(>98 \%$ Lot A0353334) (Acros Organics, New Jersey, USA); 2,6-Pyridinedicarboxylic acid (PDCA) $\left(\mathrm{C}_{7} \mathrm{H}_{5} \mathrm{NO}_{4}\right)(99.999 \%$ metals basis Lot BCBQ3850V) (Fluka, Sigma-Aldrich Co., Missouri, USA); glacial acetic acid $\left(\mathrm{C}_{2} \mathrm{H}_{4} \mathrm{O}_{2}\right)$ (99.99\% trace metals basis Lot SHBH2511V) (Sigma-Aldrich Co.); and oxalic acid $\left(\mathrm{C}_{2} \mathrm{H}_{2} \mathrm{O}_{4}\right)(99.999 \%$ trace metals basis Lot MKCC3466) (Sigma-Aldrich Co.) were dissolved in ultrapure water, then buffered with ammonium hydroxide $\left(\mathrm{NH}_{4} \mathrm{OH}\right)\left(20-22 \%\right.$ as $\left.\mathrm{NH}_{3}\right)$ (trace metal grade Lot 7115080$)$ (Fisher Scientific, New Jersey, USA), to a final $\mathrm{pH}$ of 4.5-4.8.

Preparation of an ultrapure surrogate soil matrix was carried out with the addition of the following trace pure chemicals: silicon dioxide $\left(\mathrm{SiO}_{2}\right)(99.998 \%$ trace metal basis Lot A0357680) (Acros Organics); calcium hydroxide $\left(\mathrm{Ca}(\mathrm{OH})_{2}\right)\left(99.995 \%\right.$ trace metals basis Lot MKBC4261); Iron(III) oxide $\left(\mathrm{Fe}_{2} \mathrm{O}_{3}\right)($ $>99.995 \%$ trace metals basis Lot MKCC0460); magnesium nitrate hexahydrate $\left(\mathrm{Mg}\left(\mathrm{NO}_{3}\right)_{2} \cdot 6 \mathrm{H}_{2} \mathrm{O}\right)$ $\left(99.999 \%\right.$ trace metals basis Lot MKBZ9637V); and aluminum nitrate nonahydrate $\left(\mathrm{Al}\left(\mathrm{NO}_{3}\right)_{3} \cdot 9 \mathrm{H}_{2} \mathrm{O}\right)$ (99.997\% trace metals basis Lot MKBZ3362V) (Sigma-Aldrich Co.). These were weighed out in proportions to simulate a SRM 2711a soil matrix. Trace pure potassium nitrate $\left(\mathrm{KNO}_{3}\right)(99.995 \%$ trace metals basis Lot BCBP6440V) and sodium nitrate $\left(\mathrm{NaNO}_{3}\right)(99.999 \%$ trace metals basis Lot BCBR6907V) (Sigma-Aldrich Co.) compounds will also be added to the ultrapure surrogate mixture, in the proportional amounts given in the table, when the next dissolution experiment is carried out.

Working standard solutions were prepared daily for ID-HPIC-ICPMS analyses in 7\% nitric acid $\left(\mathrm{HNO}_{3}\right)$ by diluting the stock standard solutions: IV-ICPMS-71A (10 mg/L-1) (Lot K2-MEB631044), IVICPMS-71B (10 mg/L-1) (Lot K2-MEB603127), and IV-ICPMS-71D (10 mg/L-1) (Lot K2MEB631034) (Inorganic Ventures, Virginia, USA) in ultrapure water. During IDMS quantifications, samples were spiked with enriched isotope standard: IDMS-023 (stable isotope mixture; ${ }^{150} \mathrm{Nd},{ }^{151} \mathrm{Eu}$, ${ }^{152} \mathrm{Sm},{ }^{155} \mathrm{Gd},{ }^{140} \mathrm{Ce}$ ) (Isotope Business Office, ORNL, Tennessee, USA).

For the irradiation of HEU study, New Brunswick Laboratory certified reference standard U930-D was employed.

\section{RESULTS}

\subsection{EXPANDING THE CHOSEN SEPARATION SCHEME}

The previously developed separation scheme enabled the isobaric separation and quantitation of 26 elements of interest in potential postdetonation debris. Figure 3 shows a graphical representation of the modified eluent profile, detailed previously [4]. The four eluents were deionized water, $6 \mathrm{mM}$ PDCA, 100 
$\mathrm{mM}$ oxalic acid, and $100 \mathrm{mM}$ DGA. A 5-min washing period of $100 \% 100 \mathrm{mM}$ oxalic acid was used to ensure any contaminants left on the resin were eluted. This was followed by a 5-minute washing period of $100 \%$ PDCA to remove any contaminants left from the oxalic acid in preparation for the next sample.

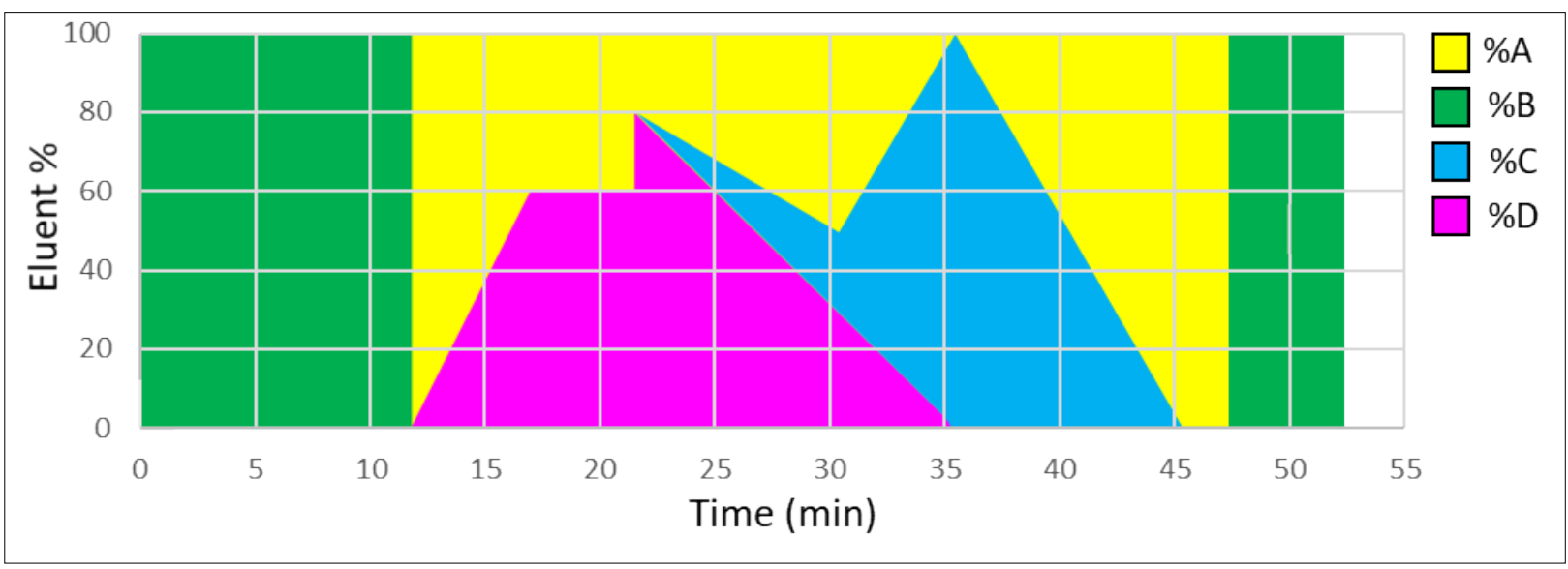

Figure 3. Gradient separation scheme using deionized water (yellow), 6 mM PDCA (green), 100 mM oxalic acid (pink), and $100 \mathrm{mM}$ DGA (blue).

To accommodate tetravalent cations via neutral species elution, the previous separation scheme was modified, allowing for the elution of the actinides plutonium and thorium and a key fission element, zirconium. A period of $100 \%$ DGA was introduced at the end of the main elution protocol, just prior to the cleaning stages of the separation scheme. The modified separation scheme is shown in Table 1 . The full injection and separation protocol executed by the Chromeleon lite 6.8 patch in the Qtegra ${ }^{\mathrm{TM}}$ software is detailed in Appendix A.

Table 1. Timings and percent contribution from each eluent for the separation scheme detailed in Figure 1

\begin{tabular}{|c|c|c|c|c|}
\hline $\begin{array}{c}\text { Time } \\
(\mathbf{m i n})\end{array}$ & $\begin{array}{c}\text { Deionized } \mathbf{H}_{\mathbf{2}} \mathbf{O} \text { (A) } \\
\text { (yellow in figure) } \\
(\mathbf{\%})\end{array}$ & $\begin{array}{c}\text { PDCA (6 mM) (B) } \\
\text { (green in figure) } \\
(\mathbf{\%})\end{array}$ & $\begin{array}{c}\text { DGA (100 mM) (C) } \\
\text { (blue in figure) } \\
(\%)\end{array}$ & $\begin{array}{c}\text { Oxalic acid (D) } \\
\text { (pink in figure) } \\
\text { (\%) }\end{array}$ \\
\hline 0 & 0 & 100 & 0 & 0 \\
\hline 12 & 0 & 100 & 0 & 0 \\
\hline 12.1 & 100 & 0 & 0 & 0 \\
\hline 17 & 40 & 0 & 0 & 60 \\
\hline 17.1 & 40 & 0 & 0 & 60 \\
\hline 21 & 40 & 0 & 0 & 80 \\
\hline 21.1 & 20 & 0 & 0 & 26 \\
\hline 30 & 51 & 0 & 23 & 0 \\
\hline 35 & 0 & 0 & 100 & 0 \\
\hline 45 & 100 & 0 & 0 & 100 \\
\hline 45.1 & 0 & 0 & 0 & 100 \\
\hline 47 & 0 & 0 & 0 & 0 \\
\hline 47.1 & 0 & 100 & 0 & 0 \\
\hline 52 & 0 & 100 & 0 & 0 \\
\hline
\end{tabular}




\subsection{ISOTOPE DILUTION MASS SPECTROMETRY}

IDMS is an analytical method for the concentration determination of an element of interest in a bulk sample/complex matrix in which separations may be required prior to analysis. In IDMS, a precisely known amount of a certified enriched isotopic standard of the element of interest, known as a "spike" or "tracer," is added to the bulk sample. After spiking, the sample is homogenized, and the element of interest is chemically purified from the bulk sample. The isotopic ratios of the spiked and unspiked samples are measured by mass spectrometry, and the analyte concentration is calculated from these isotope ratios.

As further proof of concept that chromatographic peak areas for elementally separated analytes can successfully be used for isotopic analysis and, thus, IDMS analysis, a IV-ICPMS-71A $(10 \mu \mathrm{g} / \mathrm{mL}$ multielement standard) was spiked using the IDMS-023 enriched isotope mixed lanthanide standard. Ideally, for a $1-2 \%$ uncertainty analysis, the sample should be spiked within an order of magnitude of the concentration of the analyte to be measured to see a noticeable difference in the isotopic distribution (see Figure 4).
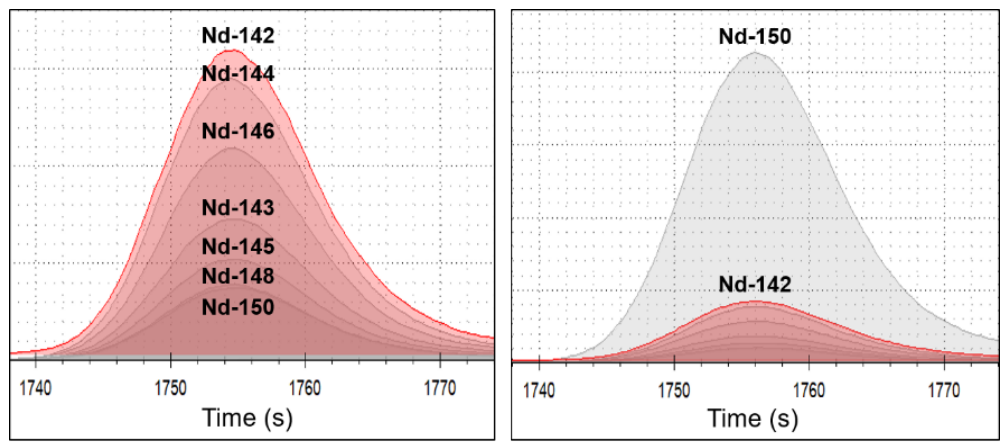

Figure 4. Chromatograms for each of the neodymium isotopes for the natural IV-ICPMS-71A standard and the natural standard spiked with the ${ }^{150} \mathrm{Nd}$ enriched IDMS-023 spike). The ${ }^{142} \mathrm{Nd}$ trace is highlighted in red in each image for clarity.

Figure 4 shows the chromatograms and resulting peaks for each of the neodymium isotopes in the natural IV-ICPMS-71A standard and the natural standard spiked with the ${ }^{150} \mathrm{Nd}$ enriched IDMS-023 spike. In both cases $125 \mathrm{pg}$ of the IV-ICPMS-71A standard was analyzed, the IV-ICPMS-71A was spiked with $\sim 125 \mathrm{pg}$ of the ${ }^{150} \mathrm{Nd}$ spike for IDMS analysis. As can be seen in Table 2, for three of the analytes, the accuracy of the analysis was $<1 \%$, with the precision of the measurements being $<1 \%$ for both neodymium and samarium. Europium and gadolinium appeared to show a larger uncertainty in the precision; this is likely due to the spike concentration for the analysis being significantly lower than the sample. However, it resulted in only a very subtle change in the isotopic distribution of the spiked sample, leading to a larger analytical uncertainty. The enriched spikes were also specifically chosen to perform IDMS measurements on nonnatural lanthanides from previous work on spent nuclear fuels and isotope production. 
Table 2. IDMS recovery numbers for a IV-ICPMS-71A (10 $\mu \mathrm{g} / \mathrm{mL}$ multielement standard), using the IDMS023 enriched isotope mixed lanthanide standard

\begin{tabular}{|c|r|r|r|r|r|c|}
\hline & \multicolumn{1}{c|}{$\begin{array}{c}\text { IDMS-A } \\
(\mathbf{\%})\end{array}$} & \multicolumn{1}{c|}{$\begin{array}{c}\text { IDMS-B } \\
(\mathbf{\%})\end{array}$} & \multicolumn{1}{c|}{$\begin{array}{c}\text { IDMS-C } \\
(\mathbf{\%})\end{array}$} & \multicolumn{1}{c|}{$\begin{array}{c}\text { Recovery } \\
(\mathbf{\%})\end{array}$} & \multicolumn{1}{c|}{$\begin{array}{c}\text { 16-SD } \\
(\mathbf{\%})\end{array}$} & Sample:Spike \\
\hline Nd & 99.8 & 99.8 & 99.1 & 99.6 & 0.8 & $1: 1.11$ \\
\hline Sm & 99.8 & 101.0 & 99.0 & 99.9 & 0.9 & $1: 0.35$ \\
\hline Eu & 108.1 & 90.5 & 100.4 & 99.7 & 7.8 & $1: 0.03$ \\
\hline Gd & 99.0 & 105.9 & 102.8 & 102.6 & 3.3 & $1: 0.04$ \\
\hline
\end{tabular}

Note: The entire IDMS procedure, including data interpretation, was performed in triplicate on

2 separate days. $\mathrm{SD}=$ standard deviation.

\subsection{DESIGNING AND PRODUCING A SURROGATE MATRIX}

The next stage in the method development was to apply the modified method to samples within a synthetic soil matrix. For the method to be successful for analyzing complex nuclear materials, it must be robust enough to be able to overcome the highly complex matrices of potential samples.

The initial sample type to be investigated will be a trace-clean synthetic soil matrix based on the elemental composition of the National Institute of Standards and Technology (NIST) 2711a standard Montana II soil. The dissolved soil surrogate, primarily composed of oxygen, silicon, aluminum, iron, and calcium, will then be doped with $\mu \mathrm{g} / \mathrm{g}$ levels of analytes (see Table 3). Preparation of the ultrapure surrogate soil matrix was carried out with the addition of select trace pure chemicals (see Section 2.2). Most of these components elute at the solvent front, should not dramatically affect the separation or retention times of the analytes, and are of minimal contamination concern for the mass spectrometer.

Table 3. Elemental composition of surrogate NIST 2711a soil showing the compound used and the elemental weight fractions

\begin{tabular}{|c|c|}
\hline Element & $\begin{array}{c}\text { Elemental weight fractions (\%) } \\
\text { and concentration }(\boldsymbol{\mu g} / \mathbf{g})\end{array}$ \\
\hline $\mathbf{S i}$ (Silicon dioxide, $\left.\mathrm{SiO}_{2}\right)$ & $17.7(750)$ \\
\hline $\mathbf{A l}$ (Aluminum nitrate nonahydrate, $\left.\mathrm{Al}\left(\mathrm{NO}_{3}\right)_{3} \cdot 9 \mathrm{H}_{2} \mathrm{O}\right)$ & $3.7(160)$ \\
\hline $\mathbf{F e}$ (Iron(III) oxide, $\left.\mathrm{Fe}_{2} \mathrm{O}_{3}\right)$ & $1.6(70)$ \\
\hline $\mathbf{C a}($ Calcium oxide, $\mathrm{CaO})$ & $1.3(60)$ \\
\hline $\mathbf{M g}$ (Magnesium nitrate hexahydrate, $\left.\mathrm{Mg}\left(\mathrm{NO}_{3}\right)_{2} \cdot 6 \mathrm{H}_{2} \mathrm{O}\right)$ & $0.6(30)$ \\
\hline
\end{tabular}

Dissolution of the trace pure surrogate mixture was performed with microwave heating (Discover SP-D ${ }^{\circ}$, CEM Corporation Matthews, NC 28106). Microwave digestion methodology was carried out according to a previously published procedure [4]. About $0.1 \mathrm{~g}$ of duplicate surrogate samples and a method blank were placed in Pyrex ${ }^{\circledR}$ pressure vessels and allowed to pickle overnight in $2 \mathrm{ml}$ nitric acid $\left(\mathrm{HNO}_{3}\right)(67 \%$ $\mathrm{v} / \mathrm{v}$, Optima Lot 1215030), and $2 \mathrm{~mL}$ hydrofluoric acid (HF) (47-51\% v/v, Optima Lot 5213102). Then surrogate samples were microwave digested under the conditions given in the table below. After cooling the samples to room temperature, $1 \mathrm{ml} \mathrm{HF}(47-51 \% \mathrm{v} / \mathrm{v}$, Optima) was added to the samples and method blank. Samples were then microwave digested under the same conditions again. Finally, excess HF was removed, and insoluble fluorides were dissolved by adding a 5\% solution of boric acid $\left(\mathrm{H}_{3} \mathrm{BO}_{3}\right)(99.999 \%$ trace metals basis Lot MKCC0193) to the samples. After the addition of boric acid, the third microwave step was omitted (see Table 4). 
Table 4. Microwave digestion settings as described in [5]

\begin{tabular}{|c|c|c|c|c|c|c|}
\hline Stage & $\begin{array}{c}\text { Temperature } \\
\left({ }^{\circ} \mathbf{C}\right)\end{array}$ & $\begin{array}{c}\text { Ramp time } \\
(\mathbf{m i n})\end{array}$ & $\begin{array}{c}\text { Hold time } \\
(\mathbf{m i n})\end{array}$ & $\begin{array}{c}\text { Pressure } \\
(\mathbf{p s i})\end{array}$ & $\begin{array}{c}\text { Power } \\
(\mathbf{W})\end{array}$ & Stirring \\
\hline 1 & 100 & $5: 00$ & $00: 10$ & 450 & 250 & Medium \\
\hline 2 & 175 & $5: 00$ & $00: 10$ & 450 & 300 & Medium \\
\hline 3 & 180 & $5: 00$ & $00: 10$ & 450 & 300 & Medium \\
\hline 4 & 180 & $10: 00$ & $00: 10$ & 450 & 300 & Medium \\
\hline 5 & 175 & $5: 00$ & $00: 10$ & 450 & 300 & Medium \\
\hline
\end{tabular}

\subsubsection{Chromatograms Produced Using the Modified Separation Scheme in the Surrogate Soil Matrix}

The following chromatograms were produced by injecting a $100 \mathrm{ng} / \mathrm{ml}$ solution of IV-ICPMS-A, IV-ICPMS-71B IV-ICPMS-71C, and IV-ICPMS-71D (5 ng injection) in the dissolved surrogate soil matrix (with $\sim 500 \mu \mathrm{g}$ Si injection) onto a CS5A column and separated using the elution protocol detailed in Section 3.2. Figure 5 shows the entire chromatogram, but with a number of $\mathrm{m} / \mathrm{z}$ traces removed for clarity. Figure 6 shows a partial chromatogram $(t=1600-2000)$, displaying the elution of the lanthanide elements showing good peak resolution despite the surrogate matrix.

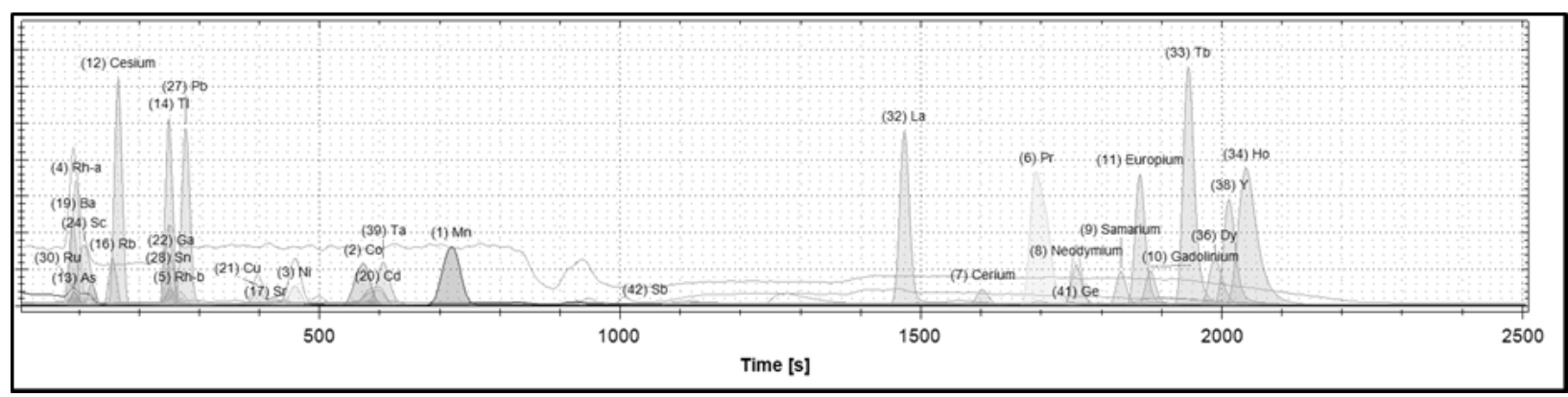

Figure 5. Chromatogram illustrating 30 of the 49 elements monitored with the modified separation scheme.

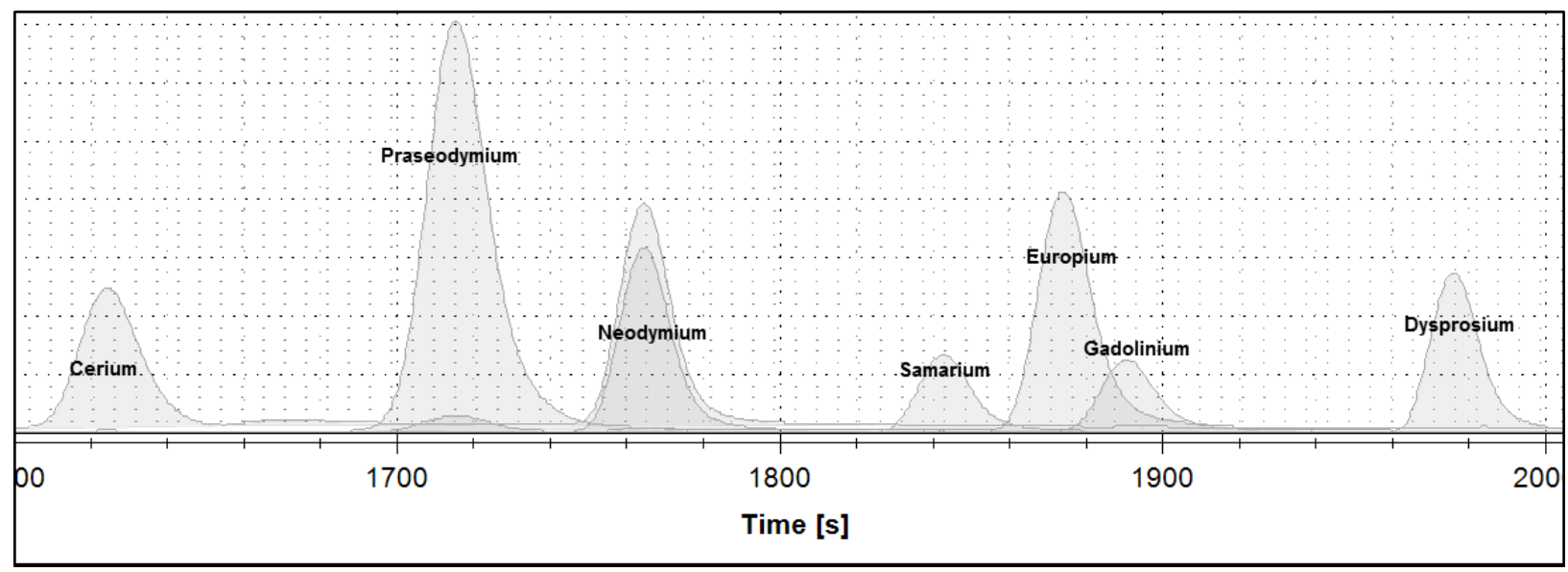

Figure 6. Partial chromatogram $(t=1600-2000)$, displaying the elution of the lanthanide elements indicating retained resolution in the surrogate matrix. 
Figure 7 shows a partial chromatogram of the transition metals $(t=200-800)$. What should be noted is that ${ }^{58} \mathrm{Fe}$ is shown on the same order of magnitude as the other first-row transition metal isotopes (e.g., ${ }^{63} \mathrm{Cu},{ }^{60} \mathrm{Ni}$ ), even though it has only a $0.28 \%$ natural abundance. This is due to a large amount of iron being present in the surrogate matrix; its inclusion at $t=275$ is to confirm separation for isobaric interferences for the nonnatural iron isotopes ${ }^{55} \mathrm{Fe}\left({ }^{55} \mathrm{Mn}, \mathrm{t}=720\right),{ }^{59} \mathrm{Fe}\left({ }^{59} \mathrm{Co}, \mathrm{t}=575\right)$, and ${ }^{60} \mathrm{Fe}\left({ }^{60} \mathrm{Ni}, \mathrm{t}=\right.$ 460).

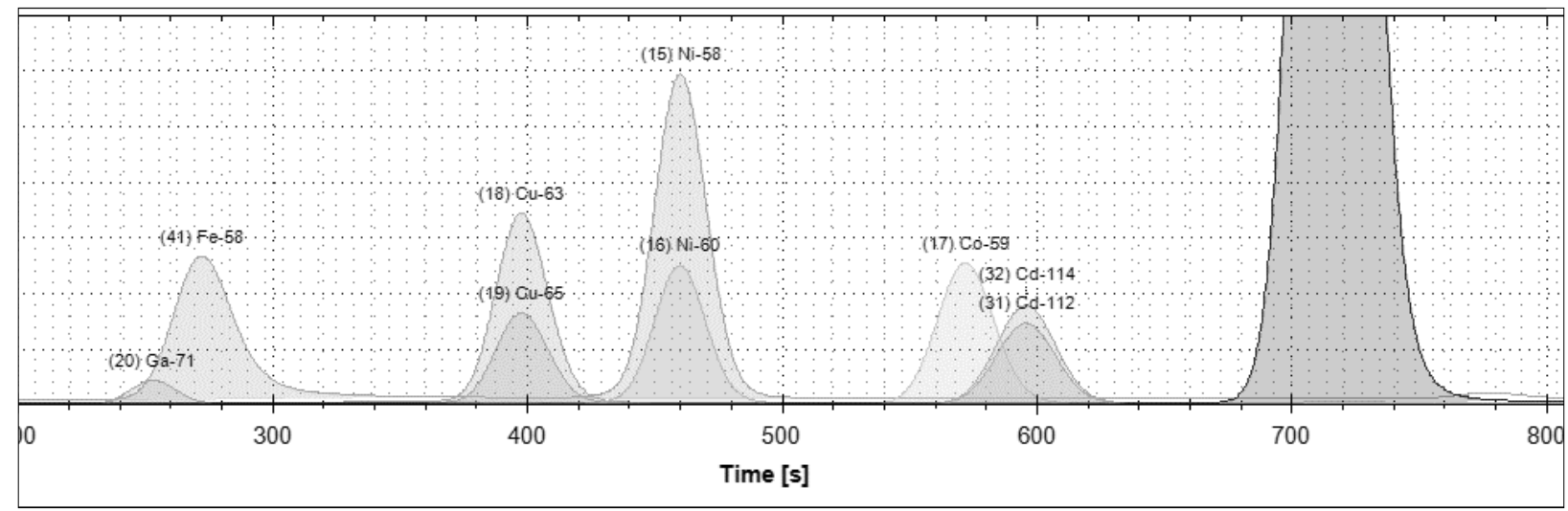

Figure 7. Partial chromatogram of the transition metals $(\mathbf{t}=\mathbf{2 0 0}-\mathbf{8 0 0}) .{ }^{58} \mathrm{Fe}$ is shown on the same order of magnitude as the other first-rowtransition metal isotopes $\left({ }^{63} \mathrm{Cu},{ }^{60} \mathrm{Ni}\right.$ e.g. $)$ even though it has only a $0.28 \%$ natural abundance. This is due to a large amount of iron being present in the surrogate matrix.

Figure 8 shows a partial chromatogram $(t=40-580)$ of the key fission elements. Cesium $(t=175)$ is shown to maintain separation from barium $(\mathrm{t}=90)$, and strontium $(\mathrm{t}=450)$ is separated from zirconium $(t=2280)$ and yttrium $(t=2013)$. Note that ruthenium elutes at two distinct times $(t=100, t=350)$.

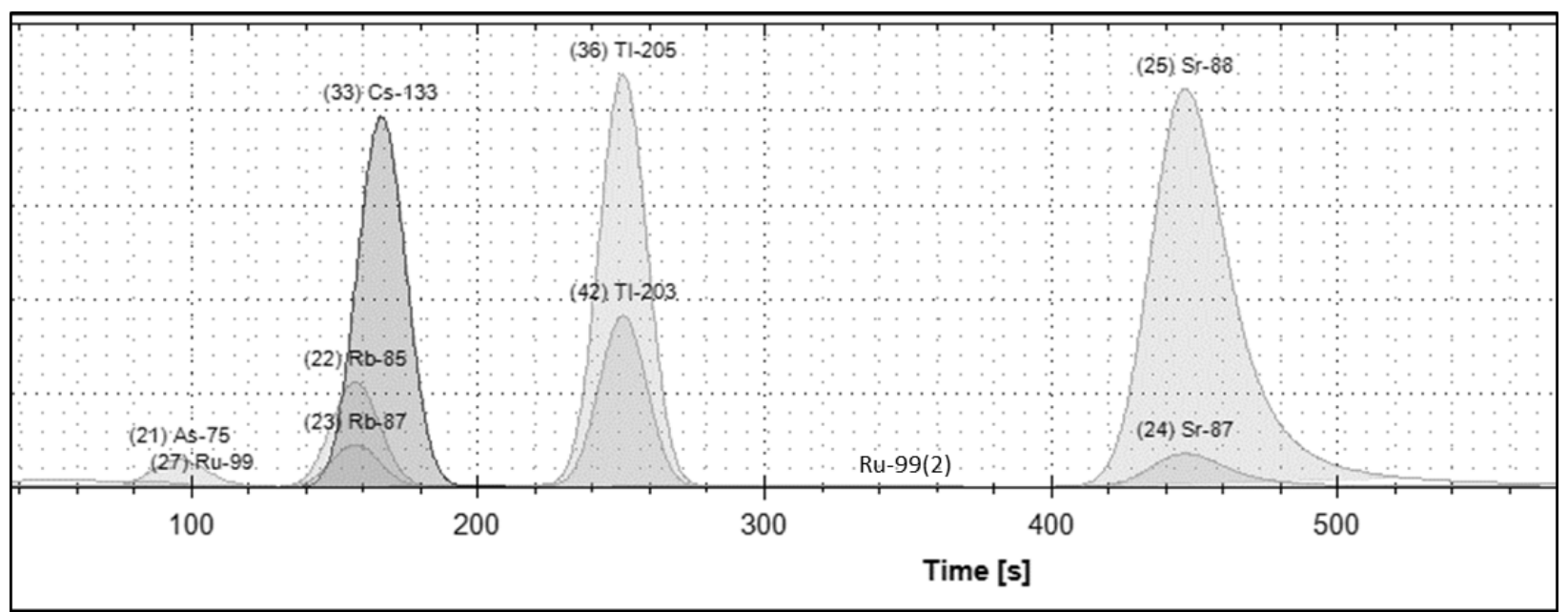

Figure 8. The $t=40-580$ region of the chromatogram illustrated in Figure 4 showing each of the individual analytes in more detail, including isotopic sensitivity, peak shape, retention time, isobaric and elemental overlap, and peak tailing.

Figure 9 (see also Table 5) shows the number of elements that have been successfully monitored and separated from isobaric interferences using the modified separation scheme. The elements highlighted in red are likely to be found in all-natural soil and glass matrices, or the acids used to dissolve them. 

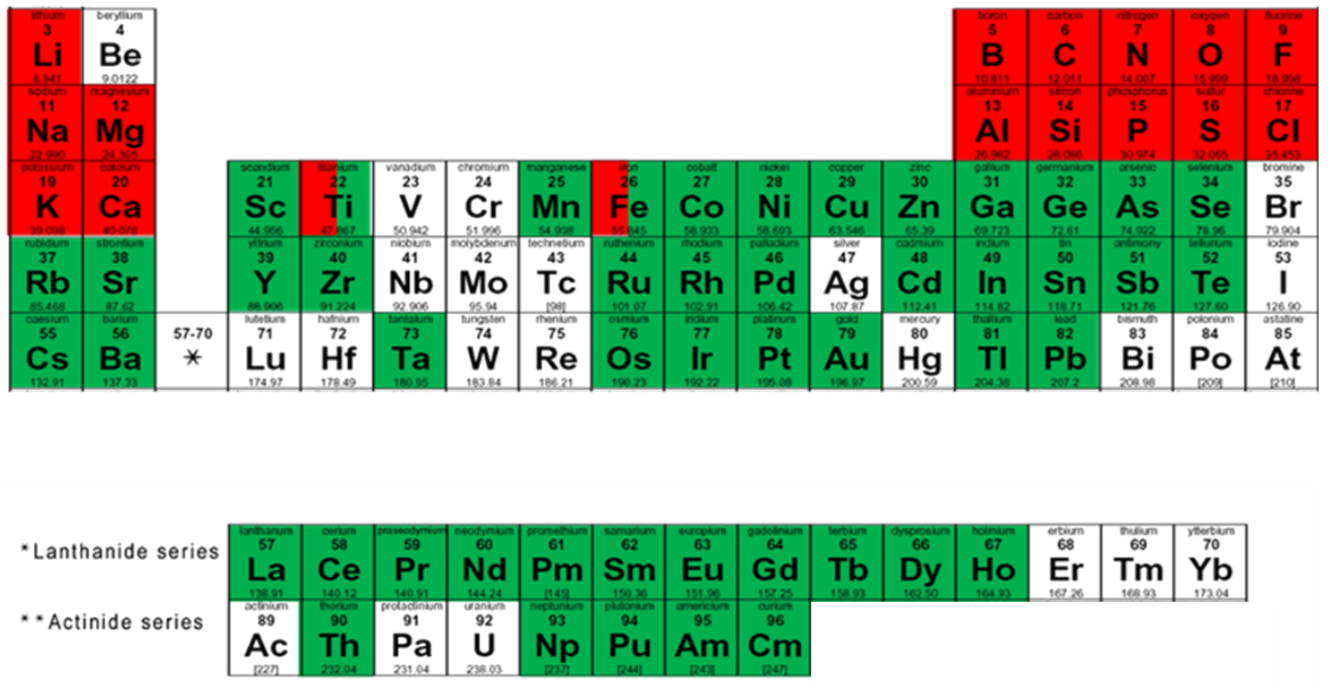

\section{Elements Successfully separated from isobaric interferences Elements expected in complex matrices}

Figure 9. Graphical representation of the 49 elements, which, apart from americium and curium, are completely separated from isobaric interferences.

\subsection{METHOD STABILITY AND REPRODUCIBILITY WITHIN SURROGATE SOIL MATRIX}

To determine the effect of a complex matrix on the stability of the method with regards to both the chromatographic separation and the peak shape and area reproducibility, nine replicates of a multielement standard ( $0.5 \mathrm{ng}$ column load) were measured. The standards were bracketed by two blank analyses to both clean the column between replicates and to extend the run to a $\sim 24 \mathrm{~h}$ period. Table 5 shows the reproducibility with relative standard deviation (RSD) for 49 elements together with their elution times in the surrogate matrix and, where measured, the original elution time as detailed previously [4].

Table 5. Elemental retention times in the original method development study and the surrogate soil matrix, together with the observed RSD of the nine replicates over the $24 \mathrm{~h}$ period

\begin{tabular}{|c|c|c|c|c|c|c|}
\hline \multirow{2}{*}{ Element } & Tracer & $\begin{array}{c}\text { In } \\
\text { dissolved } \\
\text { soil matrix }\end{array}$ & $\begin{array}{c}\text { Original study } \\
\text { In 5\% HNO } \\
\text { +Tr. HF }\end{array}$ & $\begin{array}{c}\text { Shift due } \\
\text { to matrix } \\
\text { (s) }\end{array}$ & $\begin{array}{c}\text { Stability over } \\
\text { 24 h period } \\
\text { (f measured) } \\
\text { RSD 9 replicates } \\
\text { (\%) }\end{array}$ & $\begin{array}{c}\text { Natural and } \\
\text { nonnatural } \\
\text { isobaric } \\
\text { interferences }\end{array}$ \\
\hline Barium & ${ }^{138} \mathrm{Ba}$ & 90 & & & 60.0 & $\mathrm{Ce}, \mathrm{La}, \mathrm{Nd}$ \\
\hline Arsenic & ${ }^{75} \mathrm{As}$ & 92 & & & 6.8 & \\
\hline Iridium & ${ }^{193} \mathrm{Ir}$ & 92 & 92 & 0 & 40.0 & $\mathrm{Re}, \mathrm{Pt}, \mathrm{Os}$ \\
\hline Selenium & ${ }^{77} \mathrm{Se}$ & 92 & & & 59.0 & \\
\hline Ruthenium & ${ }^{101} \mathrm{Ru}$ & $100 / 350$ & $130 / 400$ & -50 & 6.6 & $\mathrm{Rh}, \mathrm{Pd}, \mathrm{Cd}, \mathrm{Ag}$ \\
\hline Tellurium & ${ }^{125} \mathrm{Te}$ & 100 & & & 5.2 & \\
\hline Scandium & ${ }^{45} \mathrm{Sc}$ & 110 & & & 11 & $\mathrm{Ca}, \mathrm{Ti}, \mathrm{V}$ \\
\hline Neptunium & ${ }^{237} \mathrm{~Np}$ & 120 & & & 2.2 & $\mathrm{U}^{*}$ \\
\hline
\end{tabular}


Table 5. Elemental retention times in the original method development study and the surrogate soil matrix, together with the observed RSD of the nine replicates over the $24 \mathrm{~h}$ period (continued)

\begin{tabular}{|c|c|c|c|c|c|c|}
\hline \multirow[b]{2}{*}{ Element } & \multirow[b]{2}{*}{ Tracer } & \multicolumn{2}{|c|}{ Retention Time (s) } & \multirow[b]{2}{*}{$\begin{array}{l}\text { Shift due } \\
\text { to matrix } \\
\text { (s) }\end{array}$} & \multirow{2}{*}{$\begin{array}{c}\text { Stability over } \\
24 \text { h period }^{¥} \\
\text { (if measured) } \\
\text { RSD } 9 \text { replicates } \\
(\%)\end{array}$} & \multirow[b]{2}{*}{$\begin{array}{l}\text { Natural and } \\
\text { nonnatural } \\
\text { isobaric } \\
\text { interferences }\end{array}$} \\
\hline & & $\begin{array}{c}\text { In } \\
\text { dissolved } \\
\text { soil matrix }\end{array}$ & $\begin{array}{c}\text { Original study } \\
\text { in } 5 \% \\
\mathrm{HNO}_{3}+\mathrm{Tr} \text {. HF }\end{array}$ & & & \\
\hline Niobium & ${ }^{93} \mathrm{Nb}$ & 123 & & & 6.2 & \\
\hline Lithium & ${ }^{7} \mathrm{Li}$ & 126 & 129 & -3 & 3.4 & $\mathrm{Be}$ \\
\hline Osmium & ${ }^{189} \mathrm{Os}$ & 126 & & & 8.7 & \\
\hline Rubidium & ${ }^{87} \mathrm{Rb}$ & 157 & 161 & -4 & 3.5 & \\
\hline Cesium & ${ }^{133} \mathrm{Cs}$ & 165 & 190 & -25 & 3.6 & \\
\hline Thallium & ${ }^{205} \mathrm{Tl}$ & 250 & 240 & 10 & 1.4 & $\mathrm{Ba}, \mathrm{La}, \mathrm{Ce}$ \\
\hline Tin & ${ }^{118 \mathrm{Sn}}$ & 250 & & & 7.0 & \\
\hline Titanium & ${ }^{49} \mathrm{Ti}$ & 251 & & & $\mathrm{~N} / \mathrm{A}$ & \\
\hline Gallium & ${ }^{71} \mathrm{Ga}$ & 253 & & & 4.6 & $\mathrm{Zn}, \mathrm{Co}$ \\
\hline Rhodium & ${ }^{103} \mathrm{Rh}$ & 270 & & & 21.0 & $\mathrm{Ru}, \mathrm{Pd}$ \\
\hline Iron & ${ }^{58} \mathrm{Fe}$ & 276 & & & $\mathrm{~N} / \mathrm{A}$ & $\mathrm{Cr}, \mathrm{Mn}, \mathrm{Co}, \mathrm{Ni}$ \\
\hline Lead & ${ }^{208} \mathrm{~Pb}$ & 278 & & & 2.1 & $\mathrm{Hg}, \mathrm{Tl}^{*}, \mathrm{Bi}, \mathrm{Po}^{*}$ \\
\hline Zinc & ${ }^{66} \mathrm{Zn}$ & 296 & & & $\mathrm{~N} / \mathrm{A}$ & $\mathrm{Cu}$ \\
\hline Copper & ${ }^{65} \mathrm{Cu}$ & 398 & 383 & 15 & $\mathrm{~N} / \mathrm{A}$ & $\mathrm{Zn}, \mathrm{Ga}$ \\
\hline Palladium & ${ }^{105} \mathrm{Pd}$ & 427 & 411 & 16 & $\mathrm{~N} / \mathrm{A}$ & \\
\hline Strontium & ${ }^{87} \mathrm{Sr}$ & 450 & 447 & 3 & 3.5 & $\mathrm{Y}, \mathrm{Zr}$ \\
\hline Nickel & ${ }^{60} \mathrm{Ni}$ & 460 & 445 & 15 & $\mathrm{~N} / \mathrm{A}$ & $\mathrm{Fe}, \mathrm{Cu}, \mathrm{Zn}$ \\
\hline Cobalt & ${ }^{59} \mathrm{Co}$ & 575 & 553 & 22 & 40.0 & $\mathrm{Ni}, \mathrm{Fe}$ \\
\hline Cadmium & ${ }^{112} \mathrm{Cd}$ & 595 & & & 2.3 & In \\
\hline Gold & ${ }^{197} \mathrm{Au}$ & 606 & & & 7.9 & $\mathrm{Pt}, \mathrm{Os}, \mathrm{Ir}, \mathrm{Hg}$ \\
\hline Tantalum & ${ }^{181} \mathrm{Ta}$ & 607 & & & 5.3 & Hf, Re, W \\
\hline Manganese & ${ }^{55} \mathrm{Mn}$ & 720 & 695 & 25 & 40.0 & $\mathrm{Fe}$ \\
\hline Antimony & ${ }^{121} \mathrm{Sb}$ & 1020 & & & 6.2 & \\
\hline Lanthanum & ${ }^{139} \mathrm{La}$ & 1473 & & & 3.0 & \\
\hline Cerium & ${ }^{142} \mathrm{Ce}$ & 1600 & 1675 & -75 & 3.0 & $\mathrm{Pr}, \mathrm{Nd}, \mathrm{Sm}, \mathrm{Pm}$ \\
\hline Praseodymium & ${ }^{141} \mathrm{Pr}$ & 1692 & 1795 & -103 & 3.2 & $\mathrm{Nd}, \mathrm{Ce}, \mathrm{Pm}$ \\
\hline Germanium & ${ }^{73} \mathrm{Ge}$ & 1750 & & & 5.7 & \\
\hline Neodymium & ${ }^{146} \mathrm{Nd}$ & 1760 & 1862 & -102 & 2.5 & $\mathrm{Sm}, \mathrm{Gd}, \mathrm{Eu}, \mathrm{Pm}$ \\
\hline Samarium & ${ }^{147} \mathrm{Sm}$ & 1830 & 1990 & -160 & 2.0 & \\
\hline Europium & ${ }^{153} \mathrm{Eu}$ & 1865 & 2070 & -205 & 1.8 & $\mathrm{Sm}, \mathrm{Gd}^{*}, \mathrm{Dy}$ \\
\hline Gadolinium & ${ }^{157} \mathrm{Gd}$ & 1882 & 2131 & -249 & 3.4 & \\
\hline Terbium & ${ }^{159} \mathrm{~Tb}$ & 1945 & & & 3.0 & \\
\hline Curium & ${ }^{244} \mathrm{Cm}$ & 1950 & & & 1.8 & $\mathrm{Am}^{*}$ \\
\hline Americium & ${ }^{241} \mathrm{Am}$ & 1970 & & & 1.7 & $\mathrm{Cm}^{*}, \mathrm{Pu}$ \\
\hline Dysprosium & ${ }^{163} \mathrm{Dy}$ & 1990 & & & 1.7 & \\
\hline Yttrium & ${ }^{89} \mathrm{Y}$ & 2013 & & & 5.0 & \\
\hline Holmium & $165 \mathrm{Ho}$ & 2,040 & & & 2.4 & \\
\hline
\end{tabular}


Table 5. Elemental retention times in the original method development study and the surrogate soil matrix, together with the observed RSD of the nine replicates over the $24 \mathrm{~h}$ period (continued)

\begin{tabular}{|c|c|c|c|c|c|c|}
\hline \multirow[b]{2}{*}{ Element } & \multirow[b]{2}{*}{ Tracer } & \multicolumn{2}{|c|}{ Retention Time (s) } & \multirow[b]{2}{*}{$\begin{array}{l}\text { Shift due } \\
\text { to matrix } \\
\text { (s) }\end{array}$} & \multirow{2}{*}{$\begin{array}{c}\text { Stability over } \\
24 \text { h period }^{¥} \\
\text { (if measured) } \text { measu } \\
\text { RSD } 9 \text { replicates } \\
\text { (\%) }\end{array}$} & \multirow{2}{*}{$\begin{array}{c}\text { Natural and } \\
\text { nonnatural } \\
\text { isobaric } \\
\text { interferences }\end{array}$} \\
\hline & & $\begin{array}{c}\text { In } \\
\text { dissolved } \\
\text { soil matrix }\end{array}$ & $\begin{array}{l}\text { Original study } \\
\text { in } 5 \% \\
\mathrm{HNO}_{3}+\mathrm{Tr} \text {. HF }\end{array}$ & & & \\
\hline Plutonium & ${ }^{239} \mathrm{Pu}$ & 2250 & & & 10.0 & $\mathrm{Am}, \mathrm{Cm}$ \\
\hline Thorium & ${ }^{232} \mathrm{Th}$ & 2310 & & & 3.8 & $\mathrm{Ra}, \mathrm{U}$ \\
\hline Thulium & ${ }^{169} \mathrm{Tm}$ & 2910 & & & $3.0 \%$ & \\
\hline Zirconium & ${ }^{94} \mathrm{Zr}$ & 2,280 & & & $4.9 \%$ & \\
\hline
\end{tabular}

Note: The natural and nonnatural isobaric interferences are also listed. N/A = not applicable; HF = hydrofluoric acid; RSD = relative standard deviation.

*Indicates that the element will have potential isobaric overlap or that the element has not or cannot be monitored. ¥ a total of 27 samples were injected as each standard was bracketed with blank injections.

\subsection{LIMITS OF DETECTION AND QUANTITATION IN SURROGATE SOIL MATRIX}

The limits of detection (LOD) and quantitation (LOQ) for individual isotopes were calculated using a linear regression slope analysis as detailed in [4]. A $1 \mathrm{ppm}$ multielement standard was diluted to $10 \mathrm{ppb}$ using the dissolved soil matrix, and serial dilutions using the matrix resulted in a series of low-level standards with elemental column loading ranging from 5 to $500 \mathrm{pg}$. The standards were analyzed using the modified HPIC-ICPMS separation scheme, monitoring a number of isotopes to investigate the effect, if any, that a complex matrix has on the method's sensitivity.

After the peak areas were determined using the Qtegra $^{\mathrm{TM}}$ software, the data was exported to Microsoft Excel and, employing the Analysis Toolpak, linear regression analysis was carried out using the regression function. This yielded, amongst other information, the standard deviation of the y-intercept from a least-squares linear regression slope analysis. Multiplying by 3.3 yields the LOD of the isotope, and multiplying by a factor of 10 gives the LOQ. For elements with multiple isotopes, the analyzed isotope was multiplied by the isotopic contribution to yield isotopic LOD and LOQ values, which will be important when employing enriched isotope standards for IDMS analyses.

For most of the isotopes monitored in the soil matrix, the LOD and LOQ values were the same as or lower than those determined during method development (see Table 6). The likely reason for lower values is a more accurate regression analysis due to lower concentration standards being used in this study when compared to the original method development investigation (a high standard deviation [SD] of $500 \mathrm{pg}$ vs $2500 \mathrm{pg}$ in the original study). A number of isotopes previously monitored were excluded from this experiment, as they are elementally incorporated into the surrogate soil matrix. For certain isotopes${ }^{142} \mathrm{Ce}$ in this case-elevated detection limits were observed relative to the pristine study due to the presence of that isotope in the matrix in trace amounts. In these cases, the LOD and LOQ values could be calculated in the traditional manner of $3.3 \times$ and $10 \times$ the SD of $3 \times 7$ replicates of the matrix blank, taken over 3 nonconsecutive days. This is unimportant for this study, as a conservative LOD or LOQ value for ${ }^{142} \mathrm{Ce}$ can be applied based on the ${ }^{140} \mathrm{Ce}$ value. 
Table 6. LODs and LOQs for the individual isotopes monitored both with and without a dissolved surrogate soil matrix

\begin{tabular}{|c|c|c|c|c|c|}
\hline Isotope & $\begin{array}{c}\text { Isotopic LOD } \\
\text { (no matrix) } \\
\text { (pg) }\end{array}$ & $\begin{array}{c}\text { Isotopic LOD } \\
\text { (soil matrix) } \\
\text { (pg) }\end{array}$ & $\begin{array}{c}\text { Isotopic LOQ } \\
\text { (no matrix) } \\
\text { (pg) }\end{array}$ & $\begin{array}{c}\text { Isotopic LOD } \\
\text { (soil matrix) } \\
\text { (pg) }\end{array}$ & Comments \\
\hline${ }^{7} \mathrm{Li}-$ & 48.4 & & 146.5 & & Matrix Background \\
\hline${ }^{85} \mathrm{Rb}$ & 7.0 & 1.6 & 21.1 & 4.7 & \\
\hline${ }^{87} \mathrm{Rb}$ & 2.8 & & 8.6 & & Not Analyzed \\
\hline${ }^{133} \mathrm{Cs}$ & 8.5 & 1.6 & 25.7 & 4.8 & \\
\hline${ }^{9} \mathrm{Be}$ & 90.4 & 2.4 & 274.0 & 7.4 & \\
\hline${ }^{87} \mathrm{Sr}$ & 4.0 & & 12.2 & & Not Analyzed \\
\hline${ }^{88} \mathrm{Sr}$ & 37.1 & & 112.4 & & Matrix Background \\
\hline${ }^{55} \mathrm{Mn}$ & 83.6 & & 253.2 & & Matrix Background \\
\hline${ }^{59} \mathrm{Co}$ & 14.1 & & 42.6 & & Matrix Background \\
\hline${ }^{58} \mathrm{Ni}$ & 169.7 & & 514.1 & & Matrix Background \\
\hline${ }^{60} \mathrm{Ni}$ & 76.4 & & 231.6 & & Matrix Background \\
\hline${ }^{63} \mathrm{Cu}$ & 109.5 & & 331.8 & & Matrix Background \\
\hline${ }^{65} \mathrm{Cu}$ & 43.5 & & 131.8 & & Matrix Background \\
\hline${ }^{69} \mathrm{Ga}$ & 21.4 & & 64.8 & & Not Analyzed \\
\hline${ }^{75} \mathrm{As}$ & 19.4 & & 58.7 & & Not Analyzed \\
\hline${ }^{205} \mathrm{Tl}$ & 12.0 & 0.7 & 36.4 & 2.2 & \\
\hline${ }^{100} \mathrm{Ru}$ & 5.0 & & 15.2 & & Not Analyzed \\
\hline${ }^{101} \mathrm{Ru}$ & 5.6 & 6.6 & 17.0 & 20.1 & \\
\hline${ }^{103} \mathrm{Rh}$ & 16.6 & 1.3 & 50.2 & 3.9 & \\
\hline${ }^{106} \mathrm{Pd}$ & 6.5 & & 19.7 & & Not Analyzed \\
\hline${ }^{108} \mathrm{Pd}$ & 2.8 & & 8.5 & & Not Analyzed \\
\hline${ }^{112} \mathrm{Cd}$ & 5.9 & 1.9 & 17.8 & 5.9 & \\
\hline${ }^{114} \mathrm{Cd}$ & 7.2 & 1.0 & 21.9 & 2.9 & \\
\hline${ }^{193} \mathrm{Ir}$ & 6.3 & 1.1 & 19.1 & 3.3 & \\
\hline${ }^{140} \mathrm{Ce}$ & 8.1 & 7.6 & 24.6 & 22.9 & High Background \\
\hline${ }^{142} \mathrm{Ce}$ & 0.6 & 8.1 & 1.8 & 24.7 & High Background \\
\hline${ }^{141} \mathrm{Pr}$ & 25.9 & 0.5 & 78.5 & 1.5 & \\
\hline${ }^{142} \mathrm{Nd}$ & 0.4 & 0.7 & 1.2 & 2.1 & \\
\hline${ }^{144} \mathrm{Nd}$ & 1.8 & 0.7 & 5.6 & 2.0 & \\
\hline${ }^{146} \mathrm{Nd}$ & 1.3 & 1.3 & 3.9 & 3.9 & \\
\hline${ }^{147} \mathrm{Sm}$ & 2.2 & 1.5 & 6.6 & 4.5 & \\
\hline${ }^{152} \mathrm{Sm}$ & 5.2 & 1.1 & 15.8 & 3.3 & \\
\hline${ }^{151} \mathrm{Eu}$ & 1.3 & 0.8 & 4.0 & 2.3 & \\
\hline${ }^{{ }^{153} \mathrm{Eu}}$ & 2.0 & 1.0 & 6.0 & 3.0 & \\
\hline${ }^{156} \mathrm{Gd}$ & 2.5 & 0.8 & 7.7 & 2.5 & \\
\hline${ }^{157} \mathrm{Gd}$ & 2.3 & 1.3 & 7.1 & 4.0 & \\
\hline${ }^{158} \mathrm{Gd}$ & 2.2 & 0.9 & 6.7 & 2.8 & \\
\hline
\end{tabular}

Notes: Italics denote an incomplete data set due to high analyte matrix in the background. The elemental LODs and LOQs were calculated based on a linear regression slope analysis, and the isotopic LODs and LOQs were calculated by multiplying the elemental numbers by the natural isotopic abundance. *The standard deviation of the y-intercept (y) and the slope of the linear regression line (x) were calculated using the regression function in the Analysis Toolpak in Microsoft Excel. The LOD is defined as 3.3 $\times(\mathrm{y} / \mathrm{x})$, and the LOQ is defined as $10 \times(\mathrm{y} / \mathrm{x})$. 


\subsection{MEASURING FISSION PRODUCT RATIOS IN IRRADIATED HIGHLY ENRICHED URANIUM}

\subsubsection{Irradiation of Highly Enriched Uranium at the HFIR Facility}

Two HEU targets were prepared by evaporating portions of New Brunswick Laboratory certified reference standard U930-D $\left(93.2 \%{ }^{235} \mathrm{U}\right)$ into high-purity silica ampoules. The evaporation steps were unexpectedly difficult and resulted in some uncertainty in the fissile quantity. Accordingly, the flamesealed ampoules were counted on high-purity germanium (HPGe) detectors to quantify the fissile mass. Following the guidance of the Los Alamos National Laboratory PANDA (PAssive Non-Destructive Assay) manual, the $185.7 \mathrm{keV}$ gamma ray was analyzed in background-subtracted spectra. The activity determined was divided by the specific activity of ${ }^{235} \mathrm{U}(79.8 \mathrm{kBq} / \mathrm{g})$ to yield the mass. The subsequent mass values were $80 \pm 5 \mu \mathrm{g}$ and $30 \pm 3.5 \mu \mathrm{g}$ for Targets 1 and 2 , respectively. An approximate ORIGEN calculation gave the irradiation time for the larger target at 48.5 minutes for reaching about $1 \mathrm{E}+14$ fissions (see Figure 10). The number of fissions was chosen for two reasons. First, this number of fissions approaches what a real sample may be. Second, the yield of rare Earth element fission products was estimated to be well above the detection limits for the HPIC-MS instrument (see Figure 11). Finally, as determined in the first year of this research effort, the nuclear heating for targets of fissile material weighing $80 \mu \mathrm{g}$ or less should not create high-fired material that would resist dissolution.

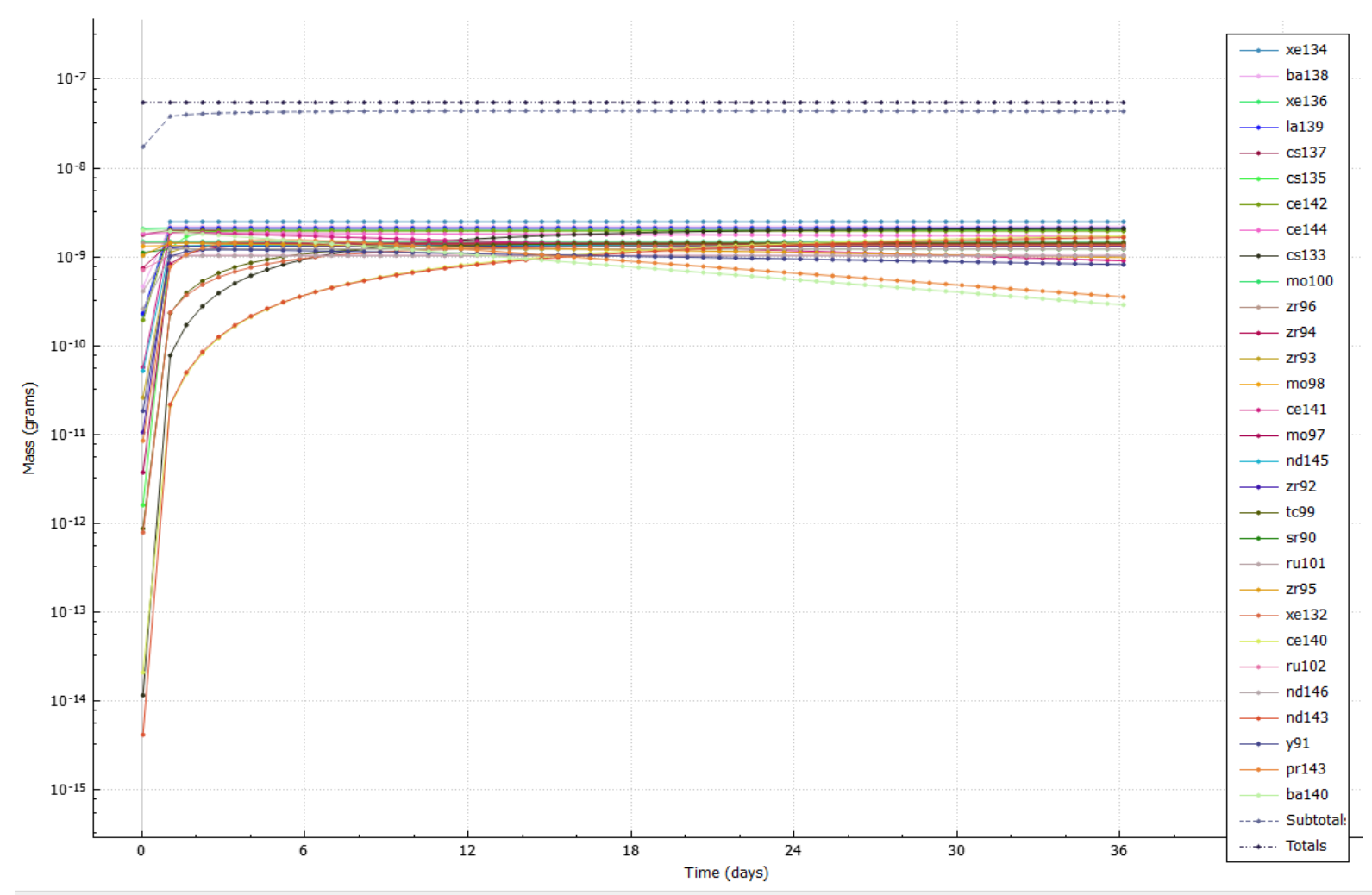

Figure 10. ORIGEN calculation for the larger target $(80 \mu \mathrm{g})$ for a $48.5 \mathrm{~h}$ irradiation period, yielding approximately $1 \mathrm{E}+14$ fissions. The graph shows the total fission quantity for the major fission isotopes over a $36 \mathrm{~d}$ decay period. 


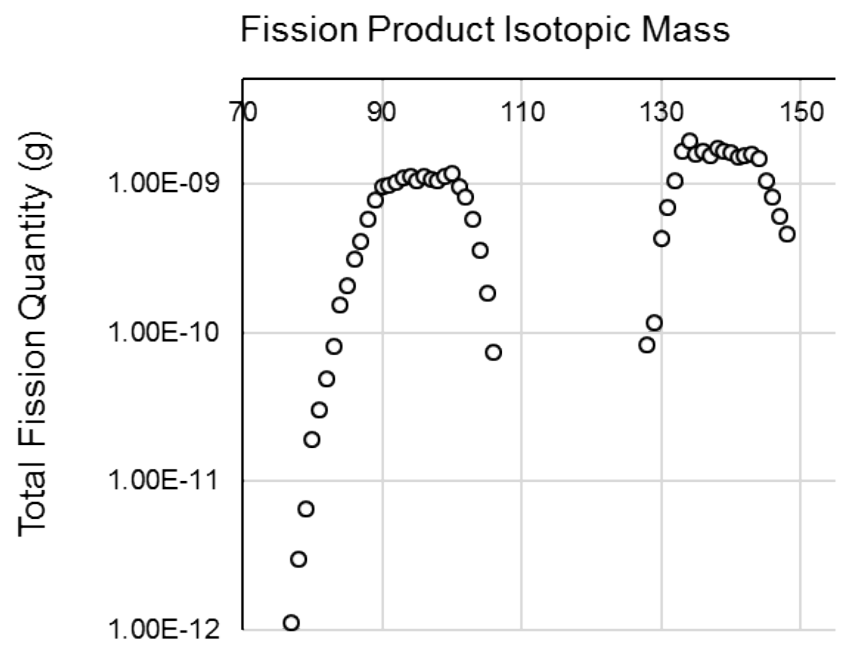

Figure 11. ORIGEN calculation for the larger target $(80 \mu \mathrm{g})$ for a $48.5 \mathrm{~h}$ irradiation period, yielding approximately $\mathbf{1 E}+\mathbf{1 4}$ fissions. The graph shows the total fission quantity for each $\mathrm{m} / \mathrm{z}$ (isotopes with the same $\mathrm{m} / \mathrm{z}$ have been summed) after a $30 \mathrm{~d}$ decay period.

On the day of irradiation, the thermal and epithermal flux populations were measured using dilute manganese and gold flux monitors, respectively. The thermal flux was $4.31 \mathrm{E}+14$, and the epithermal measured 1.09E+13, with both having units of neutrons $\mathrm{cm}-\mathrm{s}^{-1}$. For modeling purposes, the total flux over the broader neutron spectrum was calculated to be $6.69 \mathrm{E}+14$. The two targets were sealed in the same graphite rabbit and co-irradiated in the PT-1 facility (see Figure 12) to ensure very similar neutron fluence. The irradiation lasted $50 \mathrm{~min}$ and concluded at 9:34 a.m. on August 10, 2017. The dose rate of the unopened rabbit was measured the following day and totaled $1 \mathrm{Rem} / \mathrm{h}$ contact and approximately 40 $\mathrm{mRem} / \mathrm{h}$ at $30 \mathrm{~cm}$. The samples were moved to the RMAL a few days later for dissolution and analysis.

\subsubsection{Ampoule Opening, Dissolution, and ${ }^{235} \mathrm{U}$ Concentration Verification}

After a $15 \mathrm{~d}$ cooling period, both irradiated targets were shipped from the HFIR facility to Building 4501 for chemical processing and analysis. The received targets were leached and precleaned in $4 \mathrm{~N} \mathrm{HNO}_{3}$, and tare weights in Savillex leaching vessels were determined. The targets were opened by submersion in $4 \mathrm{~N}$ $\mathrm{HNO}_{3}$ in a preleached, malleable polytetrafluoroethylene (PTFE) vessel under controlled crushing with a precleaned mini-vice (Figure 13). The opened targets were then quantitatively transferred back into the pretared leaching vessels for sealed heat leaching. The vessels were heated to $\sim 80^{\circ} \mathrm{C}$ for $4 \mathrm{~h}$ and allowed to cool, and the final weight was taken to determine solution weight and volume. 


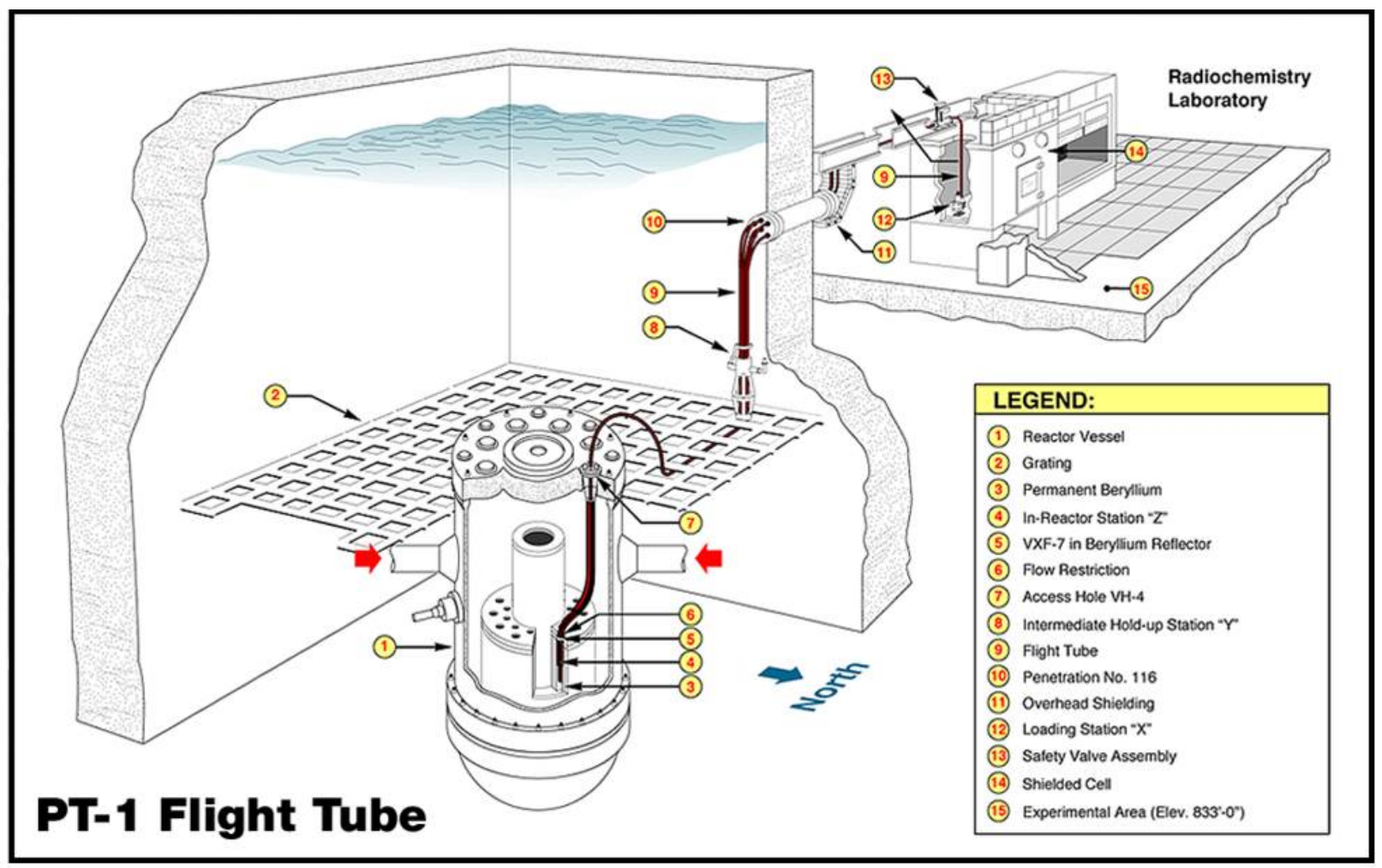

Figure 12. A diagram of the PT-1 facility highlighting the sample transfer path and irradiation site. Photographs of the shielded cell (no. 14 in figure), and the reactor (nos. 1-7 in figure) are provided in Figure 2.

To ensure complete sample dissolution, the ${ }^{235} \mathrm{U}$ content was determined for each leached target using ICPMS. The samples were externally calibrated, and a semiquantitative analysis using two independent lots of a certified ${ }^{238} \mathrm{U}$ standard (IV-ICPMS-71A, Inorganic Ventures) was performed. The determined ${ }^{235} \mathrm{U}$ content was $77.0 \pm 7.7$ and $27.4 \pm 2.7 \mu \mathrm{g}$ total for Targets 1 and 2 , respectively, well within the uncertainty of the $80 \pm 5$ and $30 \pm 3.5 \mu \mathrm{g}$ total ${ }^{235} \mathrm{U}$ determined via gamma counting prior to irradiation. This again confirmed that the nuclear heating for targets of fissile material weighing $80 \mu \mathrm{g}$ or less should not create high-fired material, as complete dissolution was achieved with minimal effort.
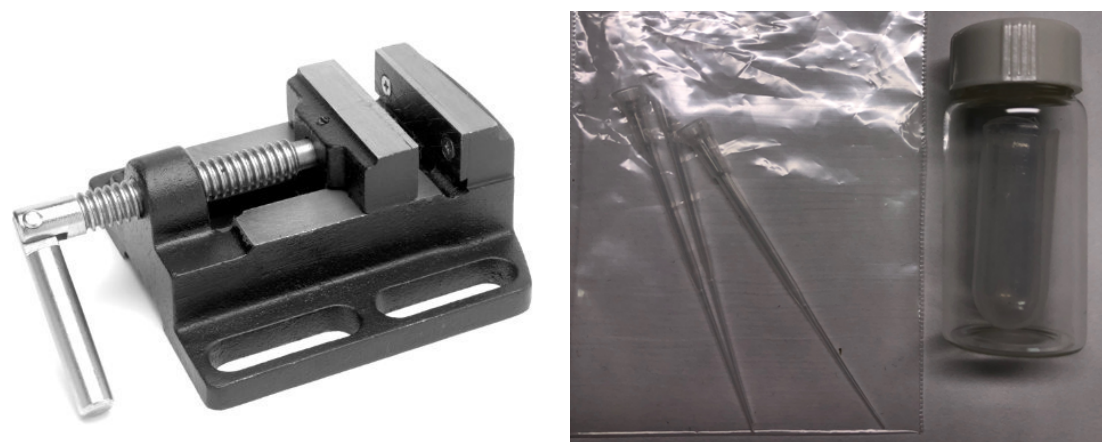

Figure 13. Photographs of the mini-vice used for opening targets (left panel) and micropipette tips and malleable leached PTFE vessel (right panel). 


\subsubsection{Fission Product Analysis of Irradiated HEU using Modified HPIC-ICPMS Method}

Fifty microliters of a $2 \times$ dilution of each of the irradiated ${ }^{235} \mathrm{U}$ leachates was analyzed for fission product isotopic content, focusing on the lanthanide fission products and cesium. The sensitivity of the method means that the lanthanide isotopic detection limit is in the high femtogram-low picogram scale. Due to method sensitivity, systematic natural contamination and background natural lanthanide content in the starting ${ }^{235} \mathrm{U}$ material is measurable. Cerium and neodymium were among the more contaminated lanthanides; however, information for each of the fission isotopes is still discernable. Among the lanthanides detected were lanthanide, cerium, praseodymium, neodymium, promethium, and samarium (see Figure 14), all predicted to be within a measurable range by the ORIGEN calculated fission.

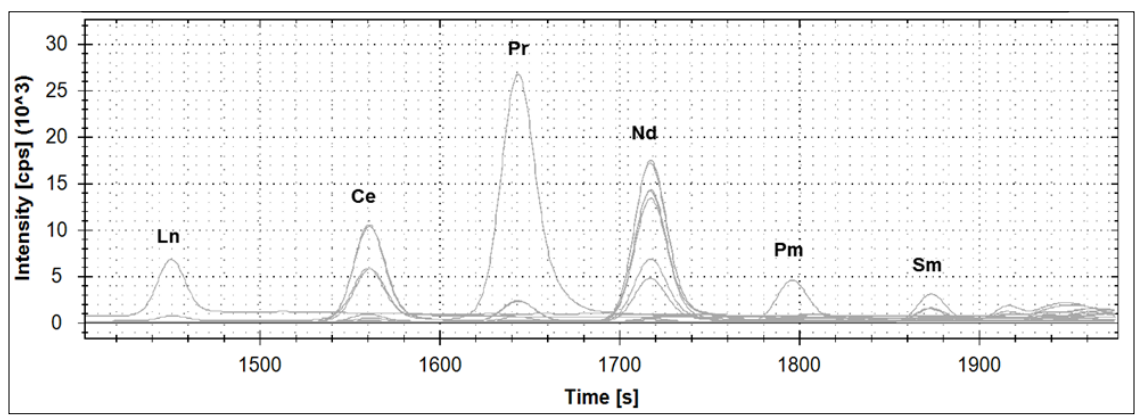

Figure 14. Partial chromatogram of $50 \mu \mathrm{L}$ of a $2 \times$ dilution of the leachate from Target 1. The chromatogram clearly shows various isotopes of the lanthanide elements. For scale, some of the more abundant isotopes from neodymium and cerium have been emitted. The lanthanide species indicated are the $\mathrm{m} / \mathrm{z} 155$ and 156 traces, ${ }^{139} \mathrm{LnO}$, and ${ }^{140} \mathrm{LnO}$.

For all fission elements measured, there seemed to be a shift in the elution times relative to those previously observed for the method development work and in the surrogate matrix (see Table 7). This is unsurprising, as a significant amount of uranium is injected onto the column and may affect the column's retention efficacy for certain elements.

\subsubsection{Separation of the $\mathrm{m} / \mathrm{z}$ trace 147 for determination of ${ }^{147} \mathrm{Nd},{ }^{147} \mathrm{Pm}$, and ${ }^{147} \mathrm{Sm}$}

One interesting finding was the clear separation of the 147 masses ${ }^{147} \mathrm{Nd},{ }^{147} \mathrm{Pm}$, and ${ }^{147} \mathrm{Sm}$. Figure 15 shows partial chromatograms of a $50 \mu \mathrm{L}$ injection of a $2 \times$ dilution of the leachate from Target 2 (above) and Target 1 (below), showing clear separation of the 147 masses. As mentioned above, the levels of natural lanthanide contamination have been seen to vary; however, the separation enables the determination of the ${ }^{147} \mathrm{Nd} /{ }^{147} \mathrm{Pm}$ ratios of 0.115 and 0.112 for Targets 1 and 2, respectively. With the ORIGEN predicted ratio at the time of analysis being 0.116 , the ratio recoveries were $99.5 \%$ and $97.0 \%$ for Targets 1 and 2, respectively. The injected isotopic mass of ${ }^{147} \mathrm{Nd}$ was $\sim 200 \mathrm{fg}$ and $\sim 600 \mathrm{fg}$ for Targets 1 and 2 , respectively.

${ }^{147} \mathrm{Nd}$ decays to ${ }^{147} \mathrm{Pm}$ with a measurable decay energy of $896 \mathrm{keV}$; on the other hand, the decay of ${ }^{147} \mathrm{Pm}$ to stable ${ }^{147} \mathrm{Sm}$ emits only a weak $\gamma$-ray at $121 \mathrm{keV}$ with an intensity of only $0.00285 \%$. Both the weak gamma and beta emissions are likely not measurable within any uncertainty in a "real-world" sample via traditional mass spectrometry or radiochemical techniques. When coupled with a semiquantitative 
Table 7. Elemental elution times for various matrices

\begin{tabular}{|l|c|c|c|}
\hline \multicolumn{1}{|c|}{ Element } & Original Elution Time (s) & $\begin{array}{c}\text { Elution Time in } \\
\text { Surrogate Soil (s) }\end{array}$ & $\begin{array}{c}\text { Elution Time in } \\
\text { Irradiated HEU (s) }\end{array}$ \\
\hline Cesium & 165 & 190 & 230 \\
\hline Strontium & 447 & 450 & 800 \\
\hline Ruthenium & $130 / 400$ & $100 / 350$ & $165 / 380$ \\
\hline Lanthanum & N/A & 1,473 & 1,450 \\
\hline Cerium & 1,675 & 1,600 & 1,560 \\
\hline Praseodymium & 1,795 & 1,692 & 1,645 \\
\hline Neodymium & 1,862 & 1,760 & 1,720 \\
\hline Samarium & 1,990 & 1,830 & 1,795 \\
\hline
\end{tabular}

Note: $\mathrm{N} / \mathrm{A}=$ not applicable.

analysis, using a ${ }^{147} \mathrm{Sm}$ tracer in a natural samarium NIST tracible standard, it should be possible to determine the ${ }^{147} \mathrm{Pm}$ concentration to within a 5-10\% uncertainty down to the low pg-high fg level.

$$
{ }^{147} \mathrm{Nd}\left(\mathrm{t}_{1 / 2}=11 \mathrm{~d}, \beta-\right) \rightarrow{ }^{147} \mathrm{Pm}\left(\mathrm{t}_{1 / 2}=2.6 \mathrm{y}, \beta-\right) \rightarrow{ }^{147} \mathrm{Sm}
$$

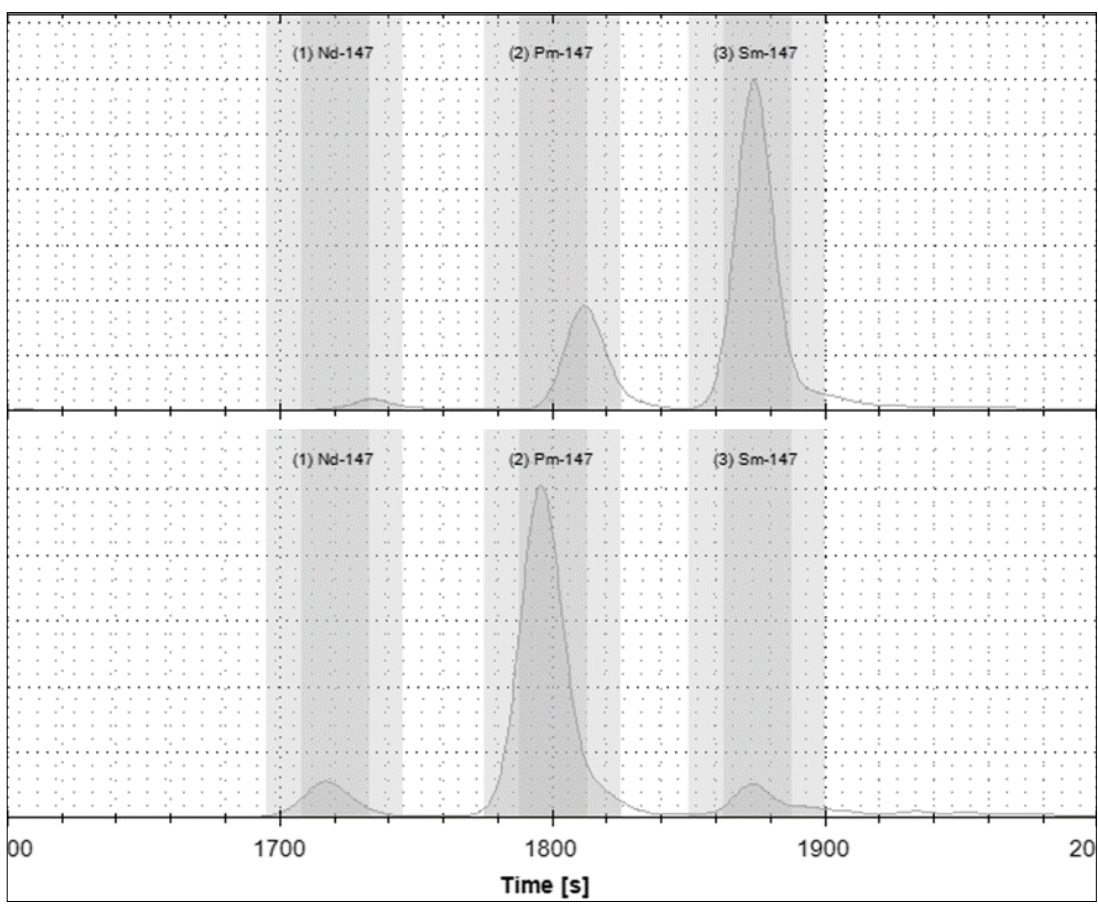

Figure 15. Partial chromatogram of $50 \mu \mathrm{L}$ of a $2 \times$ dilution of the leachate from Target 2 (top) and Target 1 (bottom), showing clear separation of the 147 masses ${ }^{147} \mathrm{Nd},{ }^{147} \mathrm{Pm}$, and ${ }^{147} \mathrm{Sm}$.

\subsubsection{Measuring the isotopes of Neodymium}

The isotopes of neodymium are among the more prominent in the ORIGEN calculated fission masses. Unfortunately, when reviewing the isotopic data, the neodymium isotopic composition measured for both targets matches neither the predicted fission nor a natural abundance; they appear to be a mixture of both. Figure 16 shows the neodymium isotopes $(t=1720)$ and fission isobaric interferences at $t=1560$ and 
$1790\left({ }^{144} \mathrm{Ce}\right.$ and $\left.{ }^{147} \mathrm{Pm}\right)$. Although ORIGEN isotopic recovery could not be calculated based on the measured data, by using the predicted fission isotopic and natural isotopic compositions, the ratio of fission to natural neodymium can be determined.

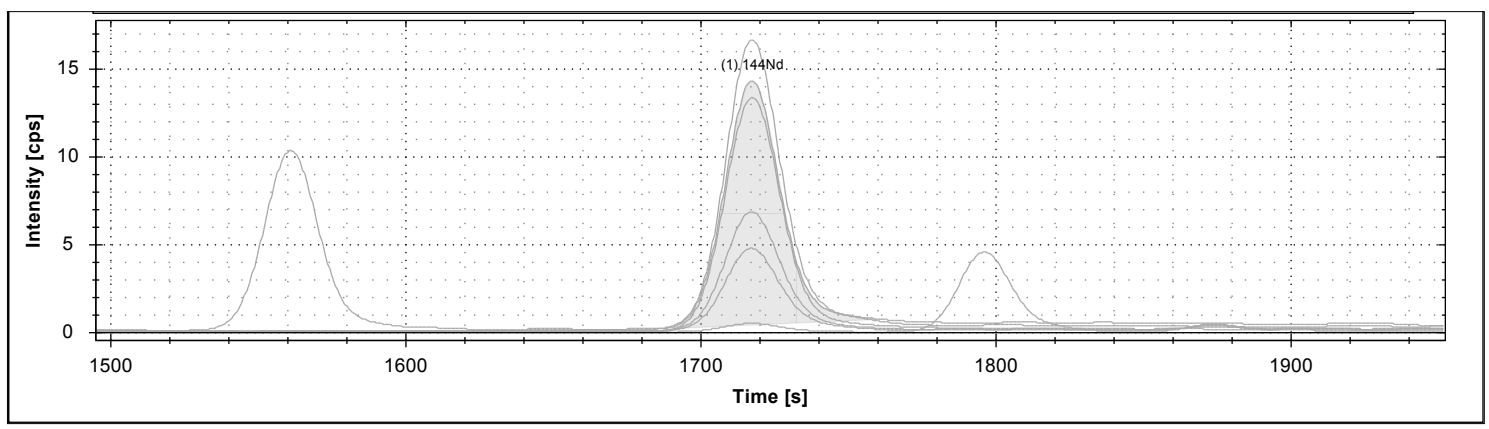

Figure 16. Partial chromatogram of $50 \mu \mathrm{L}$ of a $2 \times$ dilution of the leachate from Target 1. Figure shows the measured isotopes of neodymium as well as the isobaric interferences at $t=1560$ and 1790 , namely ${ }^{144} \mathrm{Ce}$ and ${ }^{147} \mathrm{Pm}$.

Table 8 shows the normalized natural abundance and ORIGEN predicted fission abundance of the neodymium isotopes ${ }^{144} \mathrm{Nd},{ }^{145} \mathrm{Nd},{ }^{146} \mathrm{Nd},{ }^{147} \mathrm{Nd},{ }^{148} \mathrm{Nd}$, and ${ }^{150} \mathrm{Nd}$ as well as the normalized isotopic abundances observed for each target. By using the solver function in Excel, the ratios of fission neodymium to natural neodymium were 1:0.95 and 1:1.45 for Targets 1 and 2, respectively. When compared with the calculated isotopics, the observed isotopic abundances show very good recovery for all isotopes, something that would be impossible if the isobaric interferences were not separated prior to defining the observed isotopic composition.

Table 8. The normalized natural abundance and ORIGEN predicted fission abundance of the neodymium isotopes ${ }^{144} \mathrm{Nd},{ }^{145} \mathrm{Nd},{ }^{146} \mathrm{Nd},{ }^{147} \mathrm{Nd},{ }^{148} \mathrm{Nd}$, and ${ }^{150} \mathrm{Nd}$, and the normalized isotopic abundances observed for each target

\begin{tabular}{|l|c|c|c|c|c|c|}
\hline \multicolumn{1}{|c|}{ Isotope } & $\begin{array}{c}\text { Natural } \\
\text { abundance } \\
(\%)\end{array}$ & $\begin{array}{c}\text { Fission } \\
\text { abundance } \\
(\%)\end{array}$ & $\begin{array}{c}\text { OBS } \\
\text { Target 2 } \\
(\%)\end{array}$ & $\begin{array}{c}\text { Calc 1.45:1 } \\
\text { Target 2 } \\
(\%)\end{array}$ & $\begin{array}{c}\text { OBS } \\
\text { Target 1 } \\
(\%)\end{array}$ & $\begin{array}{c}\text { Calc 0.95:1 } \\
\text { Target 1 } \\
(\%)\end{array}$ \\
\hline${ }^{144} \mathrm{Nd}$ & 39.2 & 4.6 & 21.3 & 21.5 & 24.7 & 25.1 \\
\hline${ }^{145} \mathrm{Nd}$ & 13.7 & 39.2 & 28.3 & 26.8 & 23.7 & 24.1 \\
\hline${ }^{146} \mathrm{Nd}$ & 28.3 & 30.1 & 27.3 & 29.2 & 29.6 & 29.1 \\
\hline${ }^{147} \mathrm{Nd}$ & 0 & 2.3 & 1.3 & 1.2 & 0.9 & 0.9 \\
\hline${ }^{148} \mathrm{Nd}$ & 9.6 & 17.0 & 13.2 & 13. & 12.4 & 12.6 \\
\hline${ }^{150} \mathrm{Nd}$ & 9.2 & 6.7 & 8.6 & 8.0 & 8.6 & 8.2 \\
\hline
\end{tabular}

Note: OBS $=$ Observed isotopic abundance

\subsubsection{Measuring Nonnatural Cerium Isotopes}

As seen for neodymium, the isotopes of cerium are also prominent calculated fission masses. Unlike neodymium, the natural contamination of cerium is at least an order of magnitude larger than the mass of fission cerium present. However, cerium has two nonnatural isotopes that can be measured and compared with the ratio predicted by ORIGEN. ${ }^{141} \mathrm{Ce}\left(32.5 \mathrm{~d}, \beta\right.$ decay to $\left.{ }^{141} \mathrm{Pr}\right)$ and ${ }^{144} \mathrm{Ce}\left(284.9 \mathrm{~d}, \beta\right.$ decay to ${ }^{144} \mathrm{Pr}$; $16 \mathrm{~min}, \beta$ decay to ${ }^{144} \mathrm{Nd}$ ) can be measured in both targets. Figure 17 shows the m/z $141 \mathrm{and} \mathrm{m} / \mathrm{z} 144$ chromatograms, showing clear separation between the cerium isotopes $(t=1560)$ and the ${ }^{141} \mathrm{Pr}$ and ${ }^{144} \mathrm{Nd}$ isobaric interferences (seen at $\mathrm{t}=1640$ and 1720 , respectively). When the observed ${ }^{141} \mathrm{Ce}:{ }^{144} \mathrm{Ce}$ ratios for 
Targets 1 and 2 (see Table 9) are compared with the ORIGEN ratio calculated with a $36.1 \mathrm{~d}$ decay time postirradiation, the recoveries are 99 and $98 \%$ for Targets 1 and 2 , respectively.

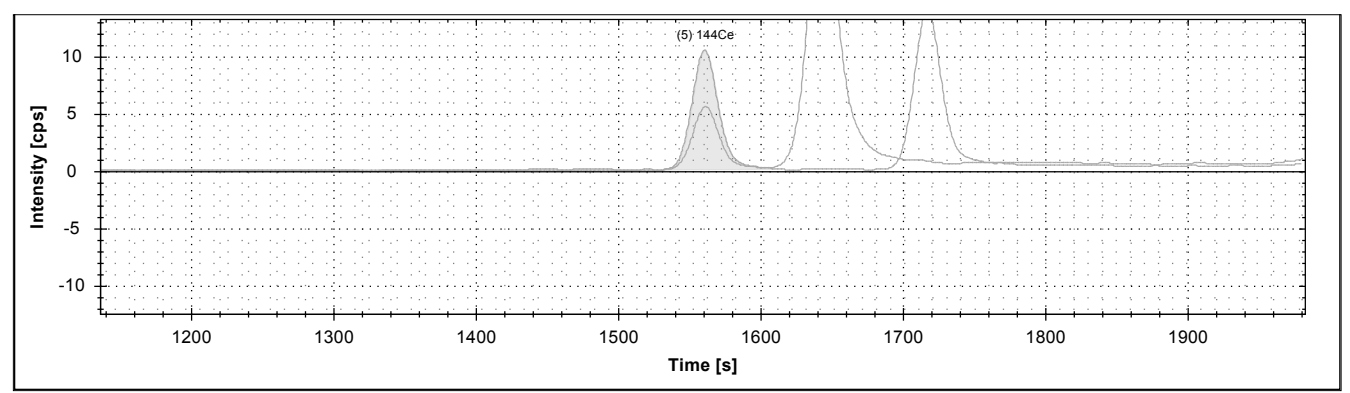

Figure 17. Partial chromatogram of $50 \mu \mathrm{L}$ of a $2 \times$ dilution of the leachate from Target 1. Figure shows the measured $\mathrm{m} / \mathrm{z} 141$ and 144 chromatograms. Clear separation is shown between the cerium isotopes $(\mathrm{t}=1560)$ and the ${ }^{141} \mathrm{Pr}$ and ${ }^{144} \mathrm{Nd}$ isobaric interferences (seen at $\mathrm{t}=1640$ and 1720 , respectively).

Table 9. The observed ${ }^{141} \mathrm{Ce}:{ }^{144} \mathrm{Ce}$ ratios for Targets 1 and 2 with the ORIGEN ratio calculated with a $36.1 \mathrm{~d}$ decay time postirradiation

\begin{tabular}{|c|c|c|c|}
\hline Target & Observed ${ }^{141} \mathrm{Ce}:{ }^{144} \mathrm{Ce}$ & Calculated ${ }^{141} \mathrm{Ce}:{ }^{144} \mathrm{Ce}$ & $\begin{array}{c}{ }^{141} \mathrm{Ce}:{ }^{144} \mathrm{Ce} \\
\% \text { recovery }\end{array}$ \\
\hline Target 1 & 0.523 & 0.528 & 99 \\
\hline Target 2 & 0.516 & 0.528 & 98 \\
\hline
\end{tabular}

\subsubsection{Measuring Nonnatural Samarium Isotope Ratios}

As with the other lanthanides, natural samarium was found as a contaminant in the dissolved targets. Target 2 was shown to have significant samarium contamination, which meant isotopic data was not useful. Target 1 , however, showed little natural contamination, and the primary nonnatural samarium isotope produced in fission ${ }^{151} \mathrm{Sm}\left(\mathrm{t}_{1 / 2}=90 \mathrm{y}\right)$ could be used to elucidate sample information.

Figure 18 shows the $\mathrm{m} / \mathrm{z} 149$ and $\mathrm{m} / \mathrm{z} 151$ chromatograms, showing clear separation between the ${ }^{151} \mathrm{Sm}$ $(\mathrm{t}=1875)$ and the contaminant ${ }^{151} \mathrm{Eu}$ isotope $(\mathrm{t}=1920)$. Target 2 (Figure 18, bottom panel) shows significant natural samarium and europium contamination. The observed ${ }^{149} \mathrm{Sm}:{ }^{151} \mathrm{Sm}$ ratio for Target 1 showed $99 \%$ recovery when compared with that calculated (2.53 vs 2.55 ). Although, as other calculated ratios don't show as good a recovery, this may just be coincidental and driven primarily by the high fission abundances of both isotopes. 


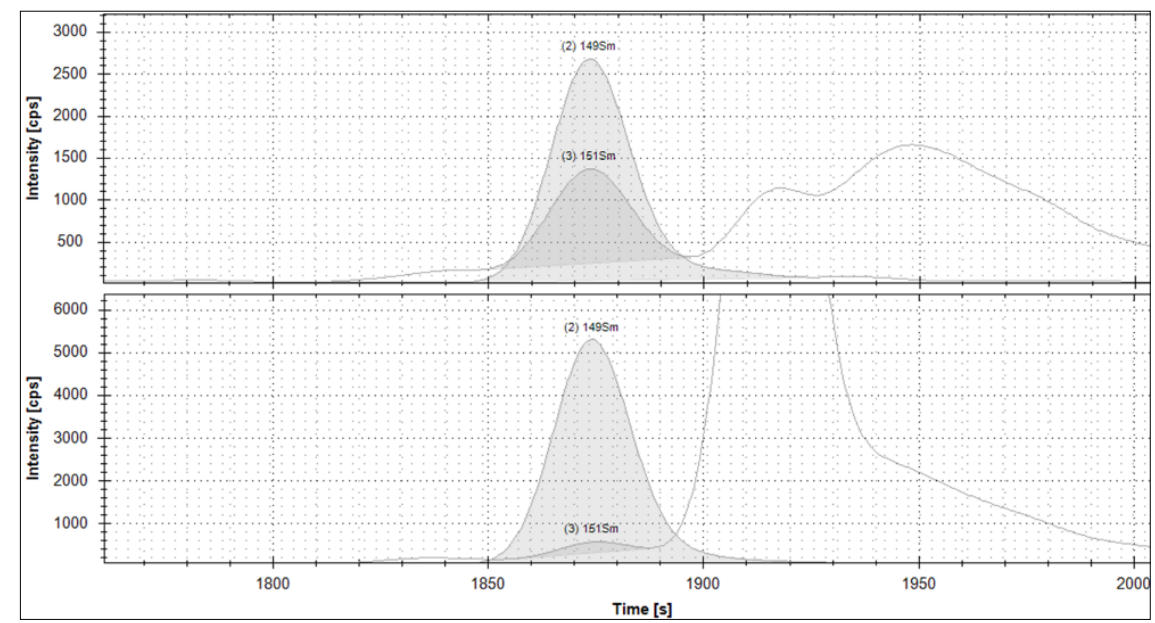

Figure 18. The $\mathrm{m} / \mathrm{z} 149$ and $\mathrm{m} / \mathrm{z} 151$ chromatograms, showing clear separation between the ${ }^{151} \mathrm{Sm}(\mathrm{t}=\mathbf{1 8 7 5})$ and the contaminant ${ }^{151} \mathrm{Eu}$ isotope $(\mathrm{t}=1920)$.

\subsubsection{Measuring Nonnatural Cesium Isotopes}

Cesium also shows slight natural contamination of ${ }^{133} \mathrm{Cs}(2 \%$ and $15 \%)$, which affects the recoveries of the isotopic composition when compared with those predicted by ORIGEN. However, as seen with cerium, cesium has two nonnatural isotopes that can be measured and compared with the ratio predicted. ${ }^{135} \mathrm{Cs}$ has an extremely long half-life $\left(2.3 \times 10^{6} \mathrm{y}\right)$ and is significantly more difficult to measure than the shorter lived ${ }^{137} \mathrm{Cs}(30.17 \mathrm{y})$. Natural ${ }^{135} \mathrm{Ba}\left(6.6 \%\right.$ natural abundance) and ${ }^{137} \mathrm{Ba}(11.2 \%$ natural abundance) present in almost all-natural samples of glass and soil will likely mask the ${ }^{135} \mathrm{Cs}$ and ${ }^{137} \mathrm{Cs}$ content when mass spectrometry methods are used. Figure 19 shows the m/z 133, m/z 135, and m/z 137 chromatograms, showing clear separation between the naturally occurring barium isotopes $(t=90)$. The barium content is three to four orders of magnitude larger than the cesium content and shows significant peak tailing; despite this, the peak picking software uses each of the individual $\mathrm{m} / \mathrm{z}$ baselines to determine peak area. When the observed ${ }^{135} \mathrm{Cs} /{ }^{137} \mathrm{Cs}$ ratios for Targets 1 and 2 (see Table 10) are compared with the ORIGEN ratio calculated with a $36.1 \mathrm{~d}$ decay time postirradiation, the recoveries are 99 and $102 \%$ for Targets 1 and 2, respectively.

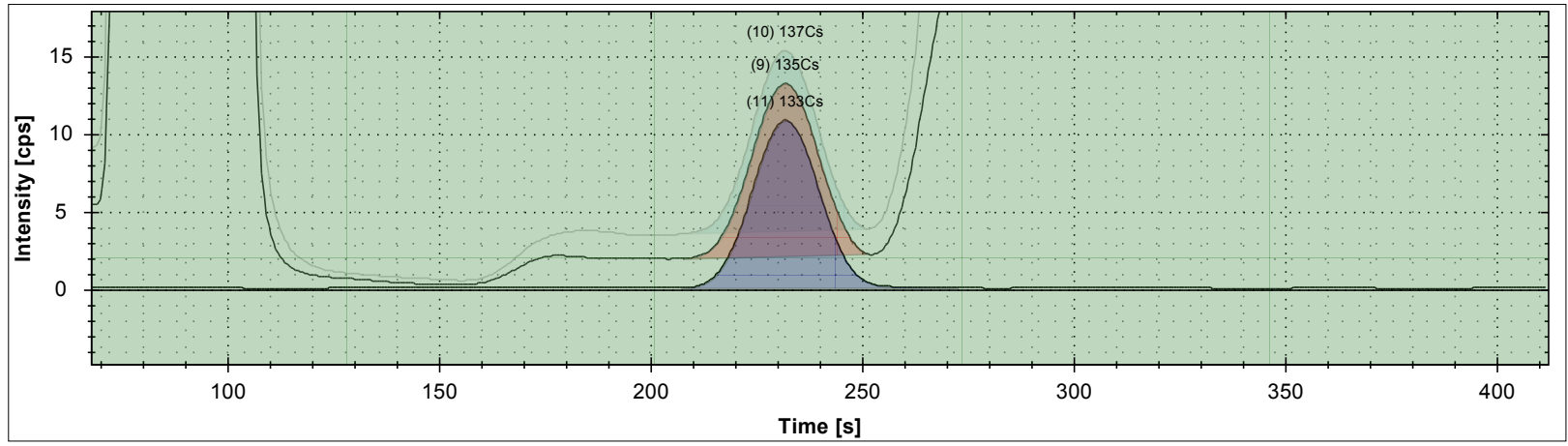

Figure 19. M/z 133, m/z 135, and m/z 137 chromatograms, showing clear separation between the naturally occurring barium isotopes ${ }^{135} \mathrm{Ba}$ and ${ }^{137} \mathrm{Ba}(\mathrm{t}=90)$ and cesium. 
Table 10. Observed cesium isotopic compositions and ${ }^{135} \mathrm{Cs}:{ }^{137} \mathrm{Cs}$ ratios for Targets 1 and 2 compared with the ORIGEN ratio calculated with a $36.1 \mathrm{~d}$ decay time postirradiation

\begin{tabular}{|c|c|c|c|c|c|c|}
\hline Target & $\begin{array}{c}{ }^{133} \mathbf{C s} \\
\text { atom } \\
(\%)\end{array}$ & $\begin{array}{c}{ }^{135} \text { Cs atom } \\
\mathbf{( \% )}\end{array}$ & $\begin{array}{c}{ }^{137} \text { Cs atom } \\
(\%)\end{array}$ & $\begin{array}{c}{ }^{135} \text { Cs: }:{ }^{137} \mathbf{C s} \\
\text { ORIGEN }\end{array}$ & $\begin{array}{c}{ }^{135} \text { Cs: }:{ }^{137} \text { Cs } \\
\text { measured }\end{array}$ & $\begin{array}{c}\mathbf{1 3 5}_{\text {Cs: }}{ }^{137} \text { Cs } \\
\text { \% recovery }\end{array}$ \\
\hline Target 1 & 33.1 & 33.5 & 33.9 & 0.999 & 0.987 & 99 \\
\hline Target 2 & 43.2 & 28.7 & 28.2 & 0.999 & 1.018 & 102 \\
\hline
\end{tabular}

\subsubsection{Measuring Ruthenium Isotopes}

Measuring the ruthenium isotopic ratio ${ }^{101} \mathrm{Ru}:{ }^{102} \mathrm{Ru}$ showed the sensitivity of the method even down to the calculated isotopic LODs (4 pg injection for Target 1). Figure 20 shows the m/z 101 and m/z 102 chromatograms for Target 1; even with both peak areas being at the detection limit for the method, the ${ }^{101} \mathrm{Ru}:{ }^{102} \mathrm{Ru}$ ratio was measured at 1.20 (1.19 calculated by ORIGEN, 101\% recovery). Target 2 showed ${ }^{101} \mathrm{Ru}$ and ${ }^{102} \mathrm{Ru}$ peak areas at barely five times background, and the error associated with it reflected the observed ${ }^{101} \mathrm{Ru}:{ }^{102} \mathrm{Ru}$ ratio of 1.05 (85\% recovery).

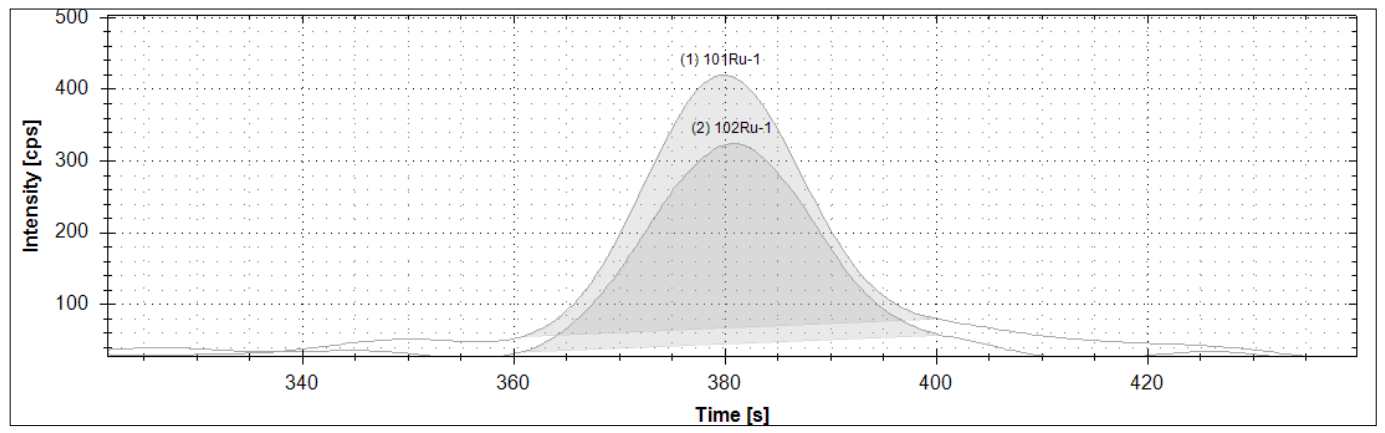

Figure 20. The $\mathrm{m} / \mathrm{z} 101$ and $\mathrm{m} / \mathrm{z} 102$ chromatograms for Target 1 showing the ${ }^{101} \mathrm{Ru}$ and ${ }^{102} \mathrm{Ru}$ peaks.

\subsubsection{Measuring Strontium Isotopes}

As seen for ruthenium, when measuring the isotopic ratio ${ }^{89} \mathrm{Sr}:{ }^{90} \mathrm{Sr}$, the sensitivity of the method can be seen even down to the calculated isotopic LODs (5 pg injection of ${ }^{89} \mathrm{Sr}$ for Target 1). Figure 21 shows the $\mathrm{m} / \mathrm{z} 89$ and $\mathrm{m} / \mathrm{z} 90$ chromatograms for Target 1; again, with both peak areas being at the detection limit for the method, the recovery of the ${ }^{89} \mathrm{Sr}:{ }^{90} \mathrm{Sr}$ ratio for both targets was $93 \%$ ( 0.46 vs 0.49 as calculated by ORIGEN). The lower recovery is probably due to mass bias effects that have been shown to be more prominent in the lower mass range; this is particularly the case for strontium [4]. A low-level natural strontium standard could be employed as a mass bias standard using the ${ }^{86} \mathrm{Sr}:{ }^{87} \mathrm{Sr}$ ratio. 


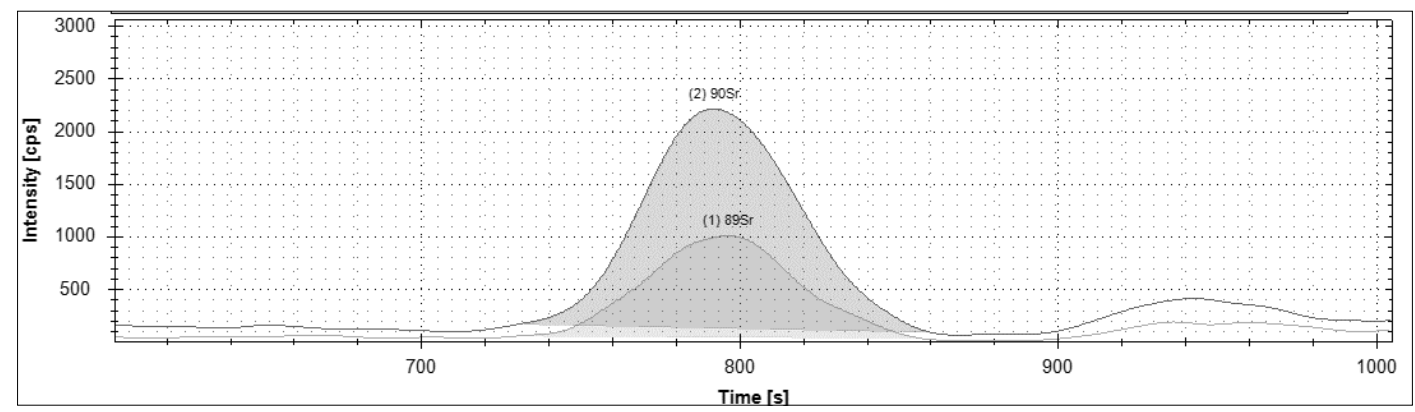

Figure 21. The $\mathrm{m} / \mathrm{z} 89$ and $\mathrm{m} / \mathrm{z} 90$ chromatograms for Target 1 showing the ${ }^{89} \mathrm{Sr}$ and ${ }^{90} \mathrm{Sr}$ peaks.

\subsubsection{Summary of Determined Fission Isotopic Ratios}

As can been seen from the summary of determined isotopic ratios for fission for Targets 1 and 2 in Table 11, the modified HPLC-ICPMS method can determine isotopic ratios to within as little as $1 \%$ of that predicted by ORIGEN. Target 1 , being $2.3 \times$ larger in mass yielded higher fission isotopic masses, which is reflected in the accuracies associated with the subsequent isotopic ratios.

Table 11. Summary of measured isotopic ratios with their recovery from that calculated in ORIGEN

\begin{tabular}{|l|c|c|c|}
\hline \multicolumn{1}{|c|}{ Element } & $\begin{array}{c}\text { ORIGEN } \\
\text { calculated ratio }\end{array}$ & $\begin{array}{c}\text { Measured ratio in } \\
\text { Target } \mathbf{1} \\
\text { (\% recovery) }\end{array}$ & $\begin{array}{c}\text { Measured ratio in } \\
\text { Target 2 } \\
\text { (\% recovery) }\end{array}$ \\
\hline${ }^{135} \mathrm{Cs}:{ }^{137} \mathrm{Cs}$ & 0.999 & $0.987(99)$ & $1.018(102)$ \\
\hline${ }^{89} \mathrm{Sr}:{ }^{90} \mathrm{Sr}$ & 0.49 & $0.46(93)$ & N/A \\
\hline${ }^{101} \mathrm{Ru}:{ }^{102} \mathrm{Ru}$ & 1.19 & $1.20(101)$ & $1.05(85)$ \\
\hline${ }^{141} \mathrm{Ce}:{ }^{144} \mathrm{Ce}$ & 0.528 & $0.523(99)$ & $0.516(98)$ \\
\hline${ }^{147} \mathrm{Nd}:{ }^{147} \mathrm{Pm}$ & 0.116 & $0.115(100)$ & $0.112(97)$ \\
\hline${ }^{149} \mathrm{Sm}:{ }^{151} \mathrm{Sm}$ & 2.55 & $2.53(99)$ & $\mathrm{N} / \mathrm{A}$ \\
\hline
\end{tabular}

Note: N/A denotes either that sample contamination prevented analysis or both of the isotopes measured fell below the LOD.

\section{CONCLUSION}

A robust and sensitive method to determine the concentration and isotopic composition of over 49 elements in a single analysis has been developed. The method robustness to complex silicon- based matrices was proven over a $24 \mathrm{~h}$ period, yielding standard deviations of approximately $5 \%$. The sensitivity of the analytical method appears to essentially be unaffected by a number of different matrices, with most of the limits of detection maintained in the low picogram range.

The study was extended to "real world" irradiated samples: Two HEU targets were irradiated to produce $\sim 1 \mathrm{E}+14$ fissions. After target leaching, the modified separation protocol was employed to investigate the isotopic compositions of a number of key fission products, namely cesium, strontium, ruthenium, lanthanum, cerium, praseodymium, neodymium, and samarium. The majority of the fission isotope ratios investigated showed a 1-2\% recovery from an ORIGEN model, even with some of the isotopic amounts being injected in the subpicogram range. The uranium matrix appeared to have little effect on the sensitivity of the method, although the elution times of some of the monitored fission products were affected. 
With the low detection limits and high robustness to matrices, this method could potentially have a major impact on the nuclear forensics community. Because commercially available equipment is employed and cleanroom-type environments are not required, the application cost is also minimal. The speed with which the developed method can be remotely performed is beneficial not only with regards to reduction of dose to the operator, but also significantly reduces analysis time.

\section{REFERENCES}

1. J. Giaquinto and B. Roach, "Demonstration of a Rapid HPLC-ICPMS Direct Coupling Technique Using IDMS,” Phase II proposal, DTRA J9-NTFC/A FY15 Solicitation, Oak Ridge National Laboratory, 2015.

2. B. T. Rearden et al. SCALE Code System, Version 6.2.1, ORNL/TM-2005/39, Oak Ridge National Laboratory, Oak Ridge, TN, 2017.

3. I. C. Gauld, G. Radulescu, G. Ilas, B. D. Murphy, M. L. Williams, and D. Wiarda, "Isotopic Depletion and Decay Methods and Analysis Capabilities in SCALE," Nuclear Technology 174, no. 2 (2011): 169.

4. B. D. Roach, C. R. Hexel, and J. M. Giaquinto, "Demonstration of a Rapid HPLC-ICPMS Direct Coupling Technique Using IDMS- Project Report: Part I,” ORNL-LTR-694, Oak Ridge National Laboratory, Oak Ridge, TN, 2017.

5. J. Ivanova et al., "On the microwave digestion of soils and sediments for determination of lanthanides and some toxic and essential elements by inductively coupled plasma source mass spectrometry", Talanta 54 (2001): 567-574. 


$$
\text { A-25 }
$$




\begin{tabular}{|c|c|c|c|}
\hline 17.000 & $\begin{array}{l}\text { FlOW } \\
\circ B= \\
\circ C= \\
\circ D=\end{array}$ & $=$ & $\begin{array}{l}1.000 \quad[\mathrm{ml} / \mathrm{min}] \\
0.0[\%] \\
0.0[\%] \\
60.0\left[\frac{\circ}{0}\right]\end{array}$ \\
\hline 21.000 & $\begin{array}{l}\mathrm{FlOW} \\
\circ \mathrm{B}= \\
\circ \mathrm{C}= \\
\circ \mathrm{D}=\end{array}$ & $=$ & $\begin{array}{l}1.000 \quad[\mathrm{ml} / \mathrm{min}] \\
0.0 \quad[\%] \\
0.0[\%] \\
60.0\left[\frac{\circ}{0}\right]\end{array}$ \\
\hline 21.100 & $\begin{array}{l}\mathrm{FlOW}= \\
\circ \mathrm{B}= \\
\circ \mathrm{C}= \\
\circ \mathrm{D}=\end{array}$ & $=$ & $\begin{array}{l}1.000 \quad[\mathrm{ml} / \mathrm{min}] \\
0.0[\%] \\
0.0\left[\frac{\circ}{0}\right] \\
80.0\left[\frac{\circ}{0}\right]\end{array}$ \\
\hline 30.000 & $\begin{array}{l}\mathrm{FlOW} \\
\circ \mathrm{B}= \\
\circ \mathrm{C}= \\
\circ \mathrm{D}=\end{array}$ & $=$ & $\begin{array}{l}1.000 \quad[\mathrm{ml} / \mathrm{min}] \\
0.0 \quad[\%] \\
23.0\left[\frac{\circ}{0}\right] \\
26.0[\%]\end{array}$ \\
\hline 35.000 & $\begin{array}{l}\mathrm{FlOW} \\
\circ \mathrm{B}= \\
\circ \mathrm{C}= \\
\circ \mathrm{D}=\end{array}$ & $=$ & $\begin{array}{l}1.000 \quad[\mathrm{ml} / \mathrm{min}] \\
0.0[\%] \\
100.0[\%] \\
0.0[\%]\end{array}$ \\
\hline 45.000 & $\begin{array}{l}\mathrm{FlOW} \\
\circ \mathrm{B}= \\
\circ \mathrm{C}= \\
\circ \mathrm{D}=\end{array}$ & $=$ & $\begin{array}{l}1.000 \quad[\mathrm{ml} / \mathrm{min}] \\
0.0[\%] \\
0.0[\%] \\
0.0[\%]\end{array}$ \\
\hline 45.100 & $\begin{array}{l}\mathrm{FlOW} \\
\circ \mathrm{B}= \\
\circ \mathrm{C}= \\
\circ \mathrm{D}=\end{array}$ & $=$ & $\begin{array}{l}1.000 \quad[\mathrm{ml} / \mathrm{min}] \\
0.0[\%] \\
0.0[\%] \\
100.0[\%]\end{array}$ \\
\hline 47.000 & $\begin{array}{l}\text { FlOW } \\
\text { B }= \\
\text { ㄷ }= \\
\circ D=\end{array}$ & $=$ & $\begin{array}{l}1.000 \quad[\mathrm{ml} / \mathrm{min}] \\
0.0[\%] \\
0.0[\%] \\
100.0[\%]\end{array}$ \\
\hline 47.100 & $\begin{array}{l}\text { FlOW } \\
\% B= \\
\% \mathrm{C}= \\
\circ \mathrm{D}=\end{array}$ & $=$ & $\begin{array}{l}1.000 \quad[\mathrm{ml} / \mathrm{min}] \\
100.0[\%] \\
0.0[\%] \\
0.0[\%]\end{array}$ \\
\hline 52.000 & $\begin{array}{l}\text { FlOW } \\
\% B= \\
\% \mathrm{C}= \\
\circ \mathrm{D}=\end{array}$ & $=$ & $\begin{array}{l}1.000 \quad[\mathrm{ml} / \mathrm{min}] \\
100.0[\%] \\
0.0[\%] \\
0.0[\%]\end{array}$ \\
\hline 52.100 & $\begin{array}{l}\text { Pump_- } \\
\text { End }\end{array}$ & 1_Pressure.AcqOff & \\
\hline
\end{tabular}




\section{APPENDIX B. PEAK DETECTION SETTINGS FOR QTEGRA ${ }^{\text {TM }}$}

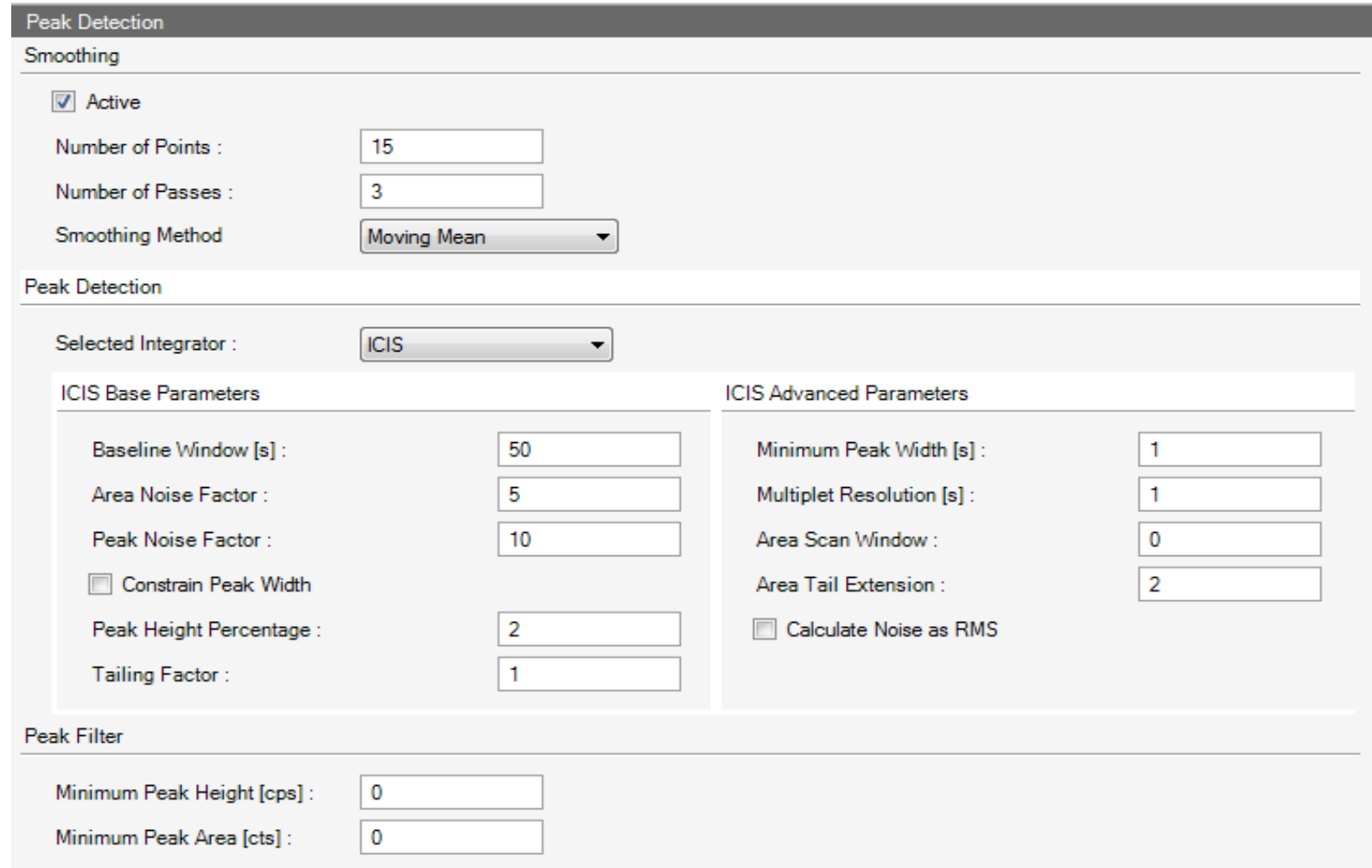


B-2 


\title{
APPENDIX C. ORIGEN CALCULATED FISSION FOR $80 \mu \mathrm{G}$ TARGET WITH 36.1 D DECAY
}

\author{
APPENDIX C.1-ORIGEN INPUT FILE FOR 80MG TARGET WITH 36.1 D DECAY
}

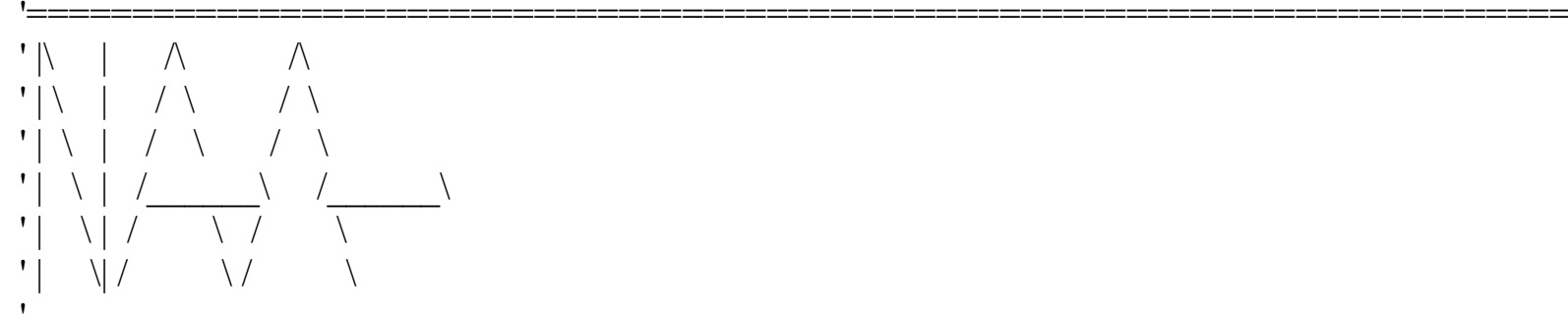

'This model was created as a part of a series for use at the Neutron 'Activation Analysis laboratory at ORNL's High Flux Isotope Reactor.

'It is meant to be used as an estimator of isotope activities, gamma 'spectra, or delayed neutron emissions created from irradiation and decay. 'This model is not in any way intended to be used for safety purposes.

'Created by Justin Knowles on 3/1/2017

'knowlesjr@ornl.gov

\footnotetext{
'=

,

$=$ couple

$*$

cross sections from 238-group JEFF-3.0/A

*

$0 \$ \$$ a3 80 a6 33 e

$1 \$ \$$ a18 238 e t

$9 * *$

$0.00000 \mathrm{E}+006.53764 \mathrm{E}+090.00000 \mathrm{E}+000.00000 \mathrm{E}+000.00000 \mathrm{E}+00$

$2.12529 \mathrm{E}+10 \quad 6.91038 \mathrm{E}+10 \quad 2.15099 \mathrm{E}+11 \quad 6.68592 \mathrm{E}+11 \quad 3.76007 \mathrm{E}+11$

$1.41645 \mathrm{E}+12 \quad 7.77543 \mathrm{E}+11 \quad 3.38427 \mathrm{E}+11 \quad 2.34859 \mathrm{E}+12 \quad 3.06335 \mathrm{E}+12$

$1.03173 \mathrm{E}+124.18700 \mathrm{E}+114.22460 \mathrm{E}+117.84341 \mathrm{E}+115.07286 \mathrm{E}+11$

$1.17709 \mathrm{E}+129.66440 \mathrm{E}+11 \quad 1.15620 \mathrm{E}+12 \quad 2.51848 \mathrm{E}+113.75272 \mathrm{E}+11$

$2.20974 \mathrm{E}+11 \quad 5.64222 \mathrm{E}+11 \quad 1.20485 \mathrm{E}+12 \quad 1.30065 \mathrm{E}+12 \quad 1.69457 \mathrm{E}+11$

$1.03350 \mathrm{E}+12 \quad 5.06611 \mathrm{E}+11 \quad 4.60539 \mathrm{E}+11 \quad 1.23223 \mathrm{E}+12 \quad 7.65327 \mathrm{E}+11$

$7.89637 \mathrm{E}+114.55362 \mathrm{E}+11 \quad 6.00943 \mathrm{E}+11 \quad 2.47461 \mathrm{E}+12 \quad 2.60531 \mathrm{E}+12$

$3.41450 \mathrm{E}+123.00265 \mathrm{E}+12 \quad 1.53566 \mathrm{E}+122.42806 \mathrm{E}+121.44259 \mathrm{E}+12$

$2.97502 \mathrm{E}+11 \quad 8.80554 \mathrm{E}+112.21527 \mathrm{E}+11 \quad 1.79509 \mathrm{E}+121.23114 \mathrm{E}+12$

$3.35564 \mathrm{E}+119.25077 \mathrm{E}+113.15937 \mathrm{E}+12 \quad 1.47739 \mathrm{E}+12 \quad 3.14011 \mathrm{E}+12$

$2.18417 \mathrm{E}+122.51179 \mathrm{E}+12 \quad 1.27825 \mathrm{E}+12 \quad 2.37213 \mathrm{E}+12 \quad 3.56627 \mathrm{E}+12$

$3.72967 \mathrm{E}+11 \quad 1.89242 \mathrm{E}+12 \quad 1.31992 \mathrm{E}+12 \quad 1.04845 \mathrm{E}+12 \quad 3.60417 \mathrm{E}+11$

$1.92606 \mathrm{E}+12 \quad 1.36619 \mathrm{E}+12 \quad 2.94783 \mathrm{E}+112.34033 \mathrm{E}+12 \quad 1.71684 \mathrm{E}+12$

$3.05683 \mathrm{E}+121.75613 \mathrm{E}+11 \quad 1.85166 \mathrm{E}+125.33343 \mathrm{E}+12 \quad 7.74750 \mathrm{E}+11$

$1.69747 \mathrm{E}+121.23996 \mathrm{E}+12 \quad 1.14473 \mathrm{E}+11 \quad 6.87529 \mathrm{E}+113.18562 \mathrm{E}+11$

$4.13064 \mathrm{E}+122.38178 \mathrm{E}+113.61179 \mathrm{E}+116.70792 \mathrm{E}+117.42830 \mathrm{E}+11$

$1.07110 \mathrm{E}+129.93626 \mathrm{E}+112.11545 \mathrm{E}+115.29555 \mathrm{E}+115.85739 \mathrm{E}+11$
}

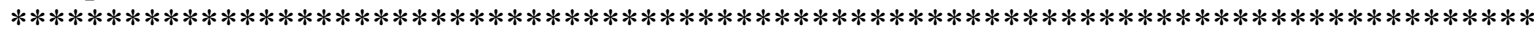


6.92547E+11 3.64256E+11 6.33301E+11 3.53510E+11 $1.02973 \mathrm{E}+12$ $2.63493 \mathrm{E}+112.61646 \mathrm{E}+11 \quad 2.85033 \mathrm{E}+11 \quad 1.97609 \mathrm{E}+112.93526 \mathrm{E}+11$ $4.43215 \mathrm{E}+112.91191 \mathrm{E}+11 \quad 3.72672 \mathrm{E}+11 \quad 3.49151 \mathrm{E}+113.68387 \mathrm{E}+11$ $1.32993 \mathrm{E}+112.91699 \mathrm{E}+11 \quad 2.73322 \mathrm{E}+11 \quad 4.78562 \mathrm{E}+112.61971 \mathrm{E}+11$ $2.92523 \mathrm{E}+111.77172 \mathrm{E}+115.57648 \mathrm{E}+11 \quad 1.67306 \mathrm{E}+114.09959 \mathrm{E}+11$ $9.44362 \mathrm{E}+111.02137 \mathrm{E}+121.13671 \mathrm{E}+127.65198 \mathrm{E}+114.49592 \mathrm{E}+11$ $5.54349 \mathrm{E}+112.99399 \mathrm{E}+119.26967 \mathrm{E}+11 \quad 7.03112 \mathrm{E}+115.93057 \mathrm{E}+11$ $5.07625 \mathrm{E}+115.54593 \mathrm{E}+11 \quad 7.05905 \mathrm{E}+119.10694 \mathrm{E}+113.87903 \mathrm{E}+11$ $1.47906 \mathrm{E}+121.13218 \mathrm{E}+12 \quad 1.32041 \mathrm{E}+12 \quad 1.37441 \mathrm{E}+12 \quad 2.62152 \mathrm{E}+11$ 4.21481E+11 4.19137E+11 4.75650E+11 4.71789E+11 $1.22082 \mathrm{E}+12$ $8.88506 \mathrm{E}+115.88234 \mathrm{E}+112.09143 \mathrm{E}+12 \quad 8.24898 \mathrm{E}+11 \quad 7.63257 \mathrm{E}+11$ $1.30085 \mathrm{E}+12 \quad 3.95942 \mathrm{E}+11 \quad 1.97068 \mathrm{E}+11 \quad 1.45405 \mathrm{E}+114.07023 \mathrm{E}+11$ $4.36030 \mathrm{E}+114.23113 \mathrm{E}+114.64615 \mathrm{E}+114.94454 \mathrm{E}+114.47548 \mathrm{E}+11$ $4.25334 \mathrm{E}+115.23038 \mathrm{E}+11 \quad 4.83764 \mathrm{E}+11 \quad 7.09742 \mathrm{E}+113.33541 \mathrm{E}+11$ $5.12924 \mathrm{E}+116.41076 \mathrm{E}+116.45263 \mathrm{E}+116.97488 \mathrm{E}+117.20185 \mathrm{E}+11$ $4.28860 \mathrm{E}+114.37312 \mathrm{E}+114.81583 \mathrm{E}+114.59525 \mathrm{E}+114.73263 \mathrm{E}+11$ $2.70268 \mathrm{E}+112.62903 \mathrm{E}+112.77108 \mathrm{E}+112.79437 \mathrm{E}+11 \quad 1.16520 \mathrm{E}+11$ $1.10042 \mathrm{E}+11 \quad 1.04800 \mathrm{E}+11 \quad 1.24114 \mathrm{E}+11 \quad 1.46069 \mathrm{E}+11 \quad 1.39350 \mathrm{E}+11$ $1.30739 \mathrm{E}+11 \quad 1.29735 \mathrm{E}+11 \quad 1.32885 \mathrm{E}+11 \quad 1.34979 \mathrm{E}+11 \quad 1.46595 \mathrm{E}+11$ $1.16650 \mathrm{E}+11 \quad 1.28782 \mathrm{E}+11 \quad 1.14453 \mathrm{E}+11 \quad 1.24725 \mathrm{E}+11 \quad 3.06171 \mathrm{E}+11$ $3.59426 \mathrm{E}+113.34344 \mathrm{E}+11 \quad 3.54727 \mathrm{E}+11 \quad 8.24201 \mathrm{E}+11 \quad 8.33444 \mathrm{E}+11$ $8.51846 \mathrm{E}+119.54553 \mathrm{E}+11 \quad 1.04123 \mathrm{E}+12 \quad 5.36854 \mathrm{E}+11 \quad 5.95681 \mathrm{E}+11$ $1.26151 \mathrm{E}+121.42038 \mathrm{E}+12 \quad 1.55013 \mathrm{E}+12 \quad 1.74155 \mathrm{E}+12 \quad 9.09198 \mathrm{E}+11$ $1.02611 \mathrm{E}+12 \quad 1.10398 \mathrm{E}+12 \quad 1.27499 \mathrm{E}+12 \quad 1.50974 \mathrm{E}+12 \quad 1.68076 \mathrm{E}+12$ $2.20298 \mathrm{E}+122.90762 \mathrm{E}+12 \quad 4.49185 \mathrm{E}+12 \quad 7.78343 \mathrm{E}+12 \quad 1.46402 \mathrm{E}+13$ $2.75673 \mathrm{E}+13 \quad 1.73711 \mathrm{E}+13 \quad 2.19944 \mathrm{E}+13 \quad 2.80448 \mathrm{E}+13 \quad 3.50640 \mathrm{E}+13$ $4.29582 \mathrm{E}+13 \quad 5.05308 \mathrm{E}+13 \quad 5.65630 \mathrm{E}+13 \quad 2.69123 \mathrm{E}+13 \quad 7.77059 \mathrm{E}+13$ $8.55019 \mathrm{E}+126.67089 \mathrm{E}+12 \quad 1.89522 \mathrm{E}+12 \quad 1.69238 \mathrm{E}+12 \quad 7.23435 \mathrm{E}+11$ $4.29661 \mathrm{E}+113.21261 \mathrm{E}+112.12981 \mathrm{E}+11 \quad 1.28844 \mathrm{E}+111.47609 \mathrm{E}+11$ $5.34235 \mathrm{E}+104.12570 \mathrm{E}+101.42609 \mathrm{E}+09$ e t

done

end

$=$ origen

solver $\{$ type $=$ cram $\}$ options $\{$ print_xs=yes $\}$

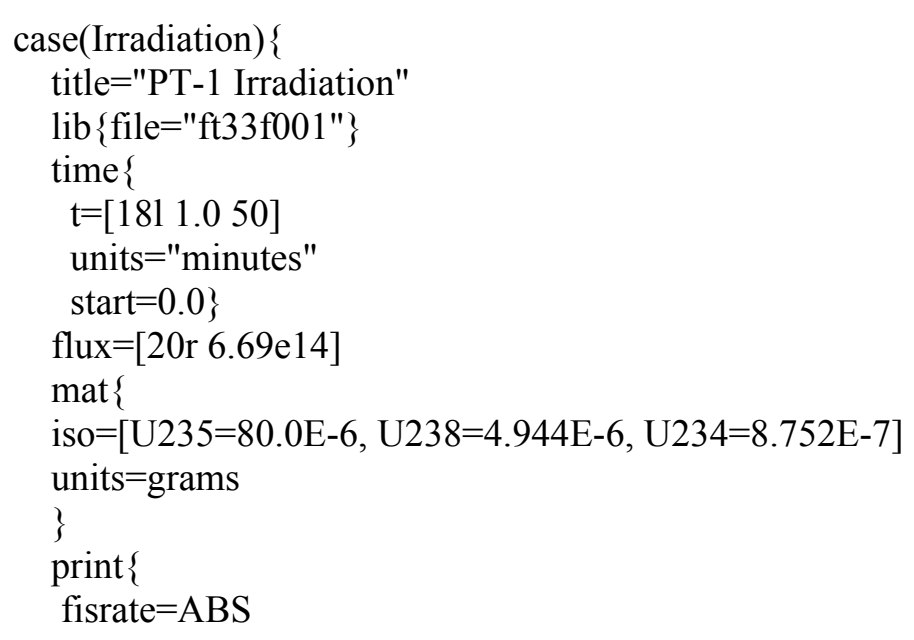




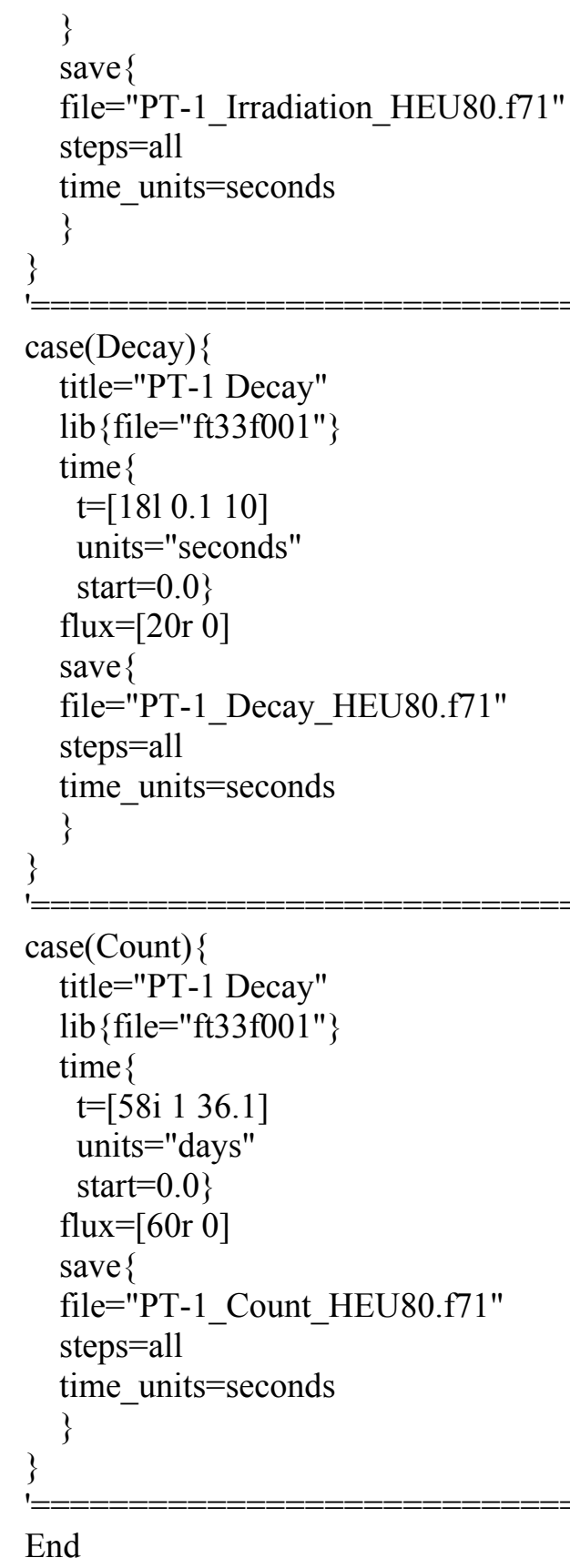

End 


\section{APPENDIX C.2-ORIGEN CALCULATED FISSION ISOTOPE MASSES FOR 80 MG TARGET WITH 36.1 D DECAY}

\begin{tabular}{|c|c|c|c|c|c|}
\hline Isotope & Mass & Isotope & Mass & Isotope & Mass \\
\hline U-235 & 7.99E-05 & Y-89 & $3.86 \mathrm{E}-10$ & Sn-122 & $4.42 \mathrm{E}-12$ \\
\hline U-238 & $4.94 \mathrm{E}-06$ & Sm-149 & $3.77 \mathrm{E}-10$ & Cd-111 & $4.38 \mathrm{E}-12$ \\
\hline U-234 & $8.75 \mathrm{E}-07$ & Pr-143 & $3.52 \mathrm{E}-10$ & Gd-156 & $4.36 \mathrm{E}-12$ \\
\hline U-236 & 9.69E-09 & Rh-103 & $3.45 \mathrm{E}-10$ & Sb-123 & $4.27 \mathrm{E}-12$ \\
\hline Xe-134 & $2.47 \mathrm{E}-09$ & $\mathrm{Nb}-95$ & $3.26 \mathrm{E}-10$ & $\mathrm{Se}-78$ & $3.83 \mathrm{E}-12$ \\
\hline Ba-138 & 2.19E-09 & Ba-140 & $2.86 \mathrm{E}-10$ & Cd-113 & $3.70 \mathrm{E}-12$ \\
\hline $\mathrm{Xe}-136$ & $2.09 \mathrm{E}-09$ & Pd-105 & $2.37 \mathrm{E}-10$ & Cd-116 & $3.60 \mathrm{E}-12$ \\
\hline La-139 & 2.09E-09 & $\mathrm{Nd}-150$ & $2.30 \mathrm{E}-10$ & Sn-120 & $3.54 \mathrm{E}-12$ \\
\hline Cs-133 & $2.06 \mathrm{E}-09$ & $\mathrm{Rb}-85$ & $2.06 \mathrm{E}-10$ & Sn-117 & $3.49 \mathrm{E}-12$ \\
\hline Cs-137 & $1.98 \mathrm{E}-09$ & $\mathrm{Kr}-84$ & $1.97 \mathrm{E}-10$ & Sn-119 & $3.47 \mathrm{E}-12$ \\
\hline Cs-135 & $1.98 \mathrm{E}-09$ & $\mathrm{Nd}-144$ & $1.56 \mathrm{E}-10$ & Sb-121 & $3.43 \mathrm{E}-12$ \\
\hline $\mathrm{Ce}-142$ & $1.94 \mathrm{E}-09$ & I-129 & $1.52 \mathrm{E}-10$ & $\mathrm{Cd}-112$ & $3.42 \mathrm{E}-12$ \\
\hline Ce-140 & $1.71 \mathrm{E}-09$ & Sm-151 & $1.48 \mathrm{E}-10$ & Cd-114 & $3.18 \mathrm{E}-12$ \\
\hline $\mathrm{Ce}-144$ & $1.70 \mathrm{E}-09$ & Mo-95 & $1.41 \mathrm{E}-10$ & Sn-118 & $3.14 \mathrm{E}-12$ \\
\hline Nd-143 & $1.65 \mathrm{E}-09$ & Te-128 & $1.05 \mathrm{E}-10$ & In-115 & $3.13 \mathrm{E}-12$ \\
\hline Mo-100 & $1.47 \mathrm{E}-09$ & $\mathrm{Kr}-83$ & $1.04 \mathrm{E}-10$ & Zr-90 & $2.59 \mathrm{E}-12$ \\
\hline Zr-96 & $1.43 \mathrm{E}-09$ & Sm-152 & $9.50 \mathrm{E}-11$ & $\mathrm{Xe}-131 \mathrm{~m}$ & $2.32 \mathrm{E}-12$ \\
\hline Zr-94 & $1.42 \mathrm{E}-09$ & $\mathrm{Ru}-106$ & 9.32E-11 & Gd-157 & $2.26 \mathrm{E}-12$ \\
\hline Tc-99 & $1.41 \mathrm{E}-09$ & Nd-147 & $7.92 \mathrm{E}-11$ & $\mathrm{He}-4$ & $1.77 \mathrm{E}-12$ \\
\hline $\mathrm{Zr}-93$ & $1.38 \mathrm{E}-09$ & $\mathrm{Pu}-239$ & $6.44 \mathrm{E}-11$ & $\mathrm{Ba}-136$ & $1.57 \mathrm{E}-12$ \\
\hline Mo-97 & $1.36 \mathrm{E}-09$ & $\mathrm{Se}-82$ & $6.23 \mathrm{E}-11$ & Se-77 & $1.44 \mathrm{E}-12$ \\
\hline Nd-145 & $1.34 \mathrm{E}-09$ & Eu-153 & $5.67 \mathrm{E}-11$ & Gd-158 & $1.22 \mathrm{E}-12$ \\
\hline $\mathrm{Xe}-132$ & $1.33 \mathrm{E}-09$ & $\mathrm{Kr}-85$ & $5.62 \mathrm{E}-11$ & Eu-156 & $1.07 \mathrm{E}-12$ \\
\hline Мo-98 & $1.33 \mathrm{E}-09$ & La-140 & $4.34 \mathrm{E}-11$ & & \\
\hline Zr-92 & $1.30 \mathrm{E}-09$ & $\mathrm{I}-131$ & $4.05 \mathrm{E}-11$ & & \\
\hline Ru-101 & $1.22 \mathrm{E}-09$ & I-127 & $4.01 \mathrm{E}-11$ & & \\
\hline Sr-90 & $1.22 \mathrm{E}-09$ & Br-81 & $3.87 \mathrm{E}-11$ & & \\
\hline Pr-141 & $1.03 \mathrm{E}-09$ & Pd-107 & $3.66 \mathrm{E}-11$ & & \\
\hline Ru-102 & $1.03 \mathrm{E}-09$ & Sm-154 & $2.69 \mathrm{E}-11$ & & \\
\hline Nd-146 & $1.02 \mathrm{E}-09$ & Se- 80 & $2.41 \mathrm{E}-11$ & & \\
\hline Zr-95 & $9.78 \mathrm{E}-10$ & $\mathrm{Xe}-133$ & $2.16 \mathrm{E}-11$ & & \\
\hline $\mathrm{Ce}-141$ & $8.99 \mathrm{E}-10$ & Sn-126 & $1.66 \mathrm{E}-11$ & & \\
\hline Xe-131 & $8.43 \mathrm{E}-10$ & Pd-108 & $1.37 \mathrm{E}-11$ & & \\
\hline Y-91 & $8.15 \mathrm{E}-10$ & Te-129m & $1.31 \mathrm{E}-11$ & & \\
\hline Sr-88 & $7.36 \mathrm{E}-10$ & Sm-147 & $1.21 \mathrm{E}-11$ & & \\
\hline Pm-147 & $6.82 \mathrm{E}-10$ & Eu-155 & $1.15 \mathrm{E}-11$ & & \\
\hline Sr-89 & $6.03 \mathrm{E}-10$ & $\mathrm{Sb}-125$ & $9.43 \mathrm{E}-12$ & & \\
\hline Nd-148 & $5.80 \mathrm{E}-10$ & Se-79 & $8.28 \mathrm{E}-12$ & & \\
\hline Te-130 & $5.52 \mathrm{E}-10$ & Ag-109 & $7.95 \mathrm{E}-12$ & & \\
\hline $\mathrm{Rb}-87$ & $5.22 \mathrm{E}-10$ & $\mathrm{Sn}-124$ & $7.78 \mathrm{E}-12$ & & \\
\hline Ru-104 & $4.58 \mathrm{E}-10$ & Pd-110 & $6.56 \mathrm{E}-12$ & & \\
\hline Zr-91 & $4.26 \mathrm{E}-10$ & Pd-106 & $6.53 \mathrm{E}-12$ & & \\
\hline $\mathrm{Kr}-86$ & $3.95 \mathrm{E}-10$ & $\mathrm{Te}-127 \mathrm{~m}$ & $6.31 \mathrm{E}-12$ & & \\
\hline Ru-103 & $3.86 \mathrm{E}-10$ & Ba-137 & $4.58 \mathrm{E}-12$ & & \\
\hline
\end{tabular}




\title{
APPENDIX D. ORIGEN CALCULATED FISSION FOR $35 \mu \mathrm{G}$ TARGET WITH 36.1 D DECAY
}

\author{
APPENDIX D.1-ORIGEN INPUT FILE FOR 35MG TARGET WITH 36.1 D DECAY
}

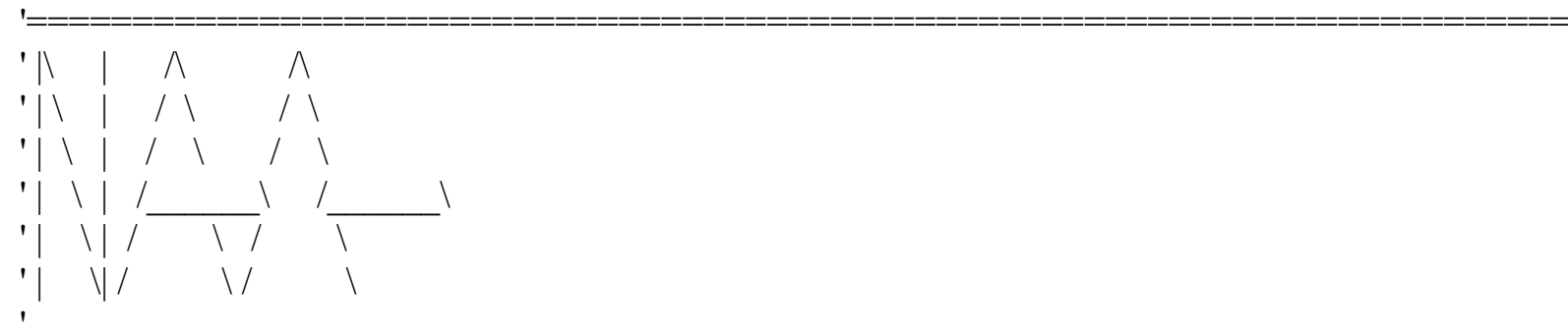

'This model was created as a part of a series for use at the Neutron 'Activation Analysis laboratory at ORNL's High Flux Isotope Reactor.

'It is meant to be used as an estimator of isotope activities, gamma 'spectra, or delayed neutron emissions created from irradiation and decay. 'This model is not in any way intended to be used for safety purposes.

'Created by Justin Knowles on 3/1/2017

'knowlesjr@ornl.gov

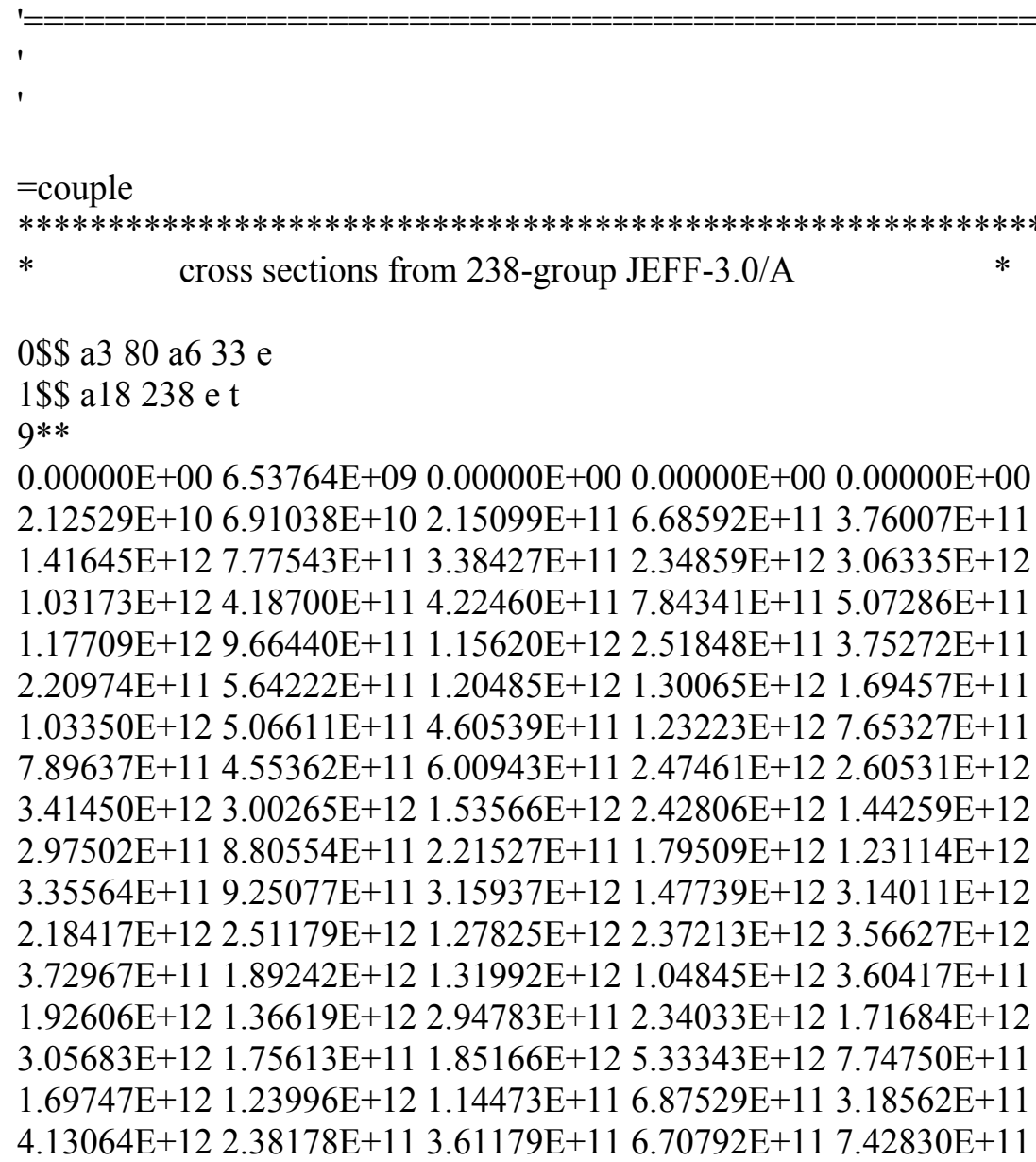

D-1 
$1.07110 \mathrm{E}+129.93626 \mathrm{E}+112.11545 \mathrm{E}+115.29555 \mathrm{E}+115.85739 \mathrm{E}+11$ $6.92547 \mathrm{E}+113.64256 \mathrm{E}+116.33301 \mathrm{E}+113.53510 \mathrm{E}+11 \quad 1.02973 \mathrm{E}+12$ $2.63493 \mathrm{E}+112.61646 \mathrm{E}+11 \quad 2.85033 \mathrm{E}+11 \quad 1.97609 \mathrm{E}+112.93526 \mathrm{E}+11$ $4.43215 \mathrm{E}+112.91191 \mathrm{E}+11 \quad 3.72672 \mathrm{E}+11 \quad 3.49151 \mathrm{E}+113.68387 \mathrm{E}+11$ $1.32993 \mathrm{E}+112.91699 \mathrm{E}+11 \quad 2.73322 \mathrm{E}+11 \quad 4.78562 \mathrm{E}+112.61971 \mathrm{E}+11$ $2.92523 \mathrm{E}+111.77172 \mathrm{E}+115.57648 \mathrm{E}+11 \quad 1.67306 \mathrm{E}+114.09959 \mathrm{E}+11$ $9.44362 \mathrm{E}+11 \quad 1.02137 \mathrm{E}+121.13671 \mathrm{E}+127.65198 \mathrm{E}+114.49592 \mathrm{E}+11$ $5.54349 \mathrm{E}+112.99399 \mathrm{E}+119.26967 \mathrm{E}+117.03112 \mathrm{E}+115.93057 \mathrm{E}+11$ $5.07625 \mathrm{E}+115.54593 \mathrm{E}+11 \quad 7.05905 \mathrm{E}+119.10694 \mathrm{E}+113.87903 \mathrm{E}+11$ $1.47906 \mathrm{E}+121.13218 \mathrm{E}+12 \quad 1.32041 \mathrm{E}+12 \quad 1.37441 \mathrm{E}+12 \quad 2.62152 \mathrm{E}+11$ 4.21481E+11 4.19137E+11 4.75650E+11 4.71789E+11 $1.22082 \mathrm{E}+12$ $8.88506 \mathrm{E}+115.88234 \mathrm{E}+112.09143 \mathrm{E}+12 \quad 8.24898 \mathrm{E}+117.63257 \mathrm{E}+11$ $1.30085 \mathrm{E}+12 \quad 3.95942 \mathrm{E}+11 \quad 1.97068 \mathrm{E}+11 \quad 1.45405 \mathrm{E}+114.07023 \mathrm{E}+11$ $4.36030 \mathrm{E}+114.23113 \mathrm{E}+114.64615 \mathrm{E}+114.94454 \mathrm{E}+114.47548 \mathrm{E}+11$ $4.25334 \mathrm{E}+115.23038 \mathrm{E}+11 \quad 4.83764 \mathrm{E}+11 \quad 7.09742 \mathrm{E}+113.33541 \mathrm{E}+11$ $5.12924 \mathrm{E}+116.41076 \mathrm{E}+116.45263 \mathrm{E}+116.97488 \mathrm{E}+117.20185 \mathrm{E}+11$ $4.28860 \mathrm{E}+114.37312 \mathrm{E}+114.81583 \mathrm{E}+114.59525 \mathrm{E}+114.73263 \mathrm{E}+11$ $2.70268 \mathrm{E}+112.62903 \mathrm{E}+112.77108 \mathrm{E}+112.79437 \mathrm{E}+11 \quad 1.16520 \mathrm{E}+11$ $1.10042 \mathrm{E}+11 \quad 1.04800 \mathrm{E}+11 \quad 1.24114 \mathrm{E}+11 \quad 1.46069 \mathrm{E}+11 \quad 1.39350 \mathrm{E}+11$ $1.30739 \mathrm{E}+11 \quad 1.29735 \mathrm{E}+11 \quad 1.32885 \mathrm{E}+11 \quad 1.34979 \mathrm{E}+11 \quad 1.46595 \mathrm{E}+11$ $1.16650 \mathrm{E}+11 \quad 1.28782 \mathrm{E}+11 \quad 1.14453 \mathrm{E}+11 \quad 1.24725 \mathrm{E}+11 \quad 3.06171 \mathrm{E}+11$ $3.59426 \mathrm{E}+113.34344 \mathrm{E}+11 \quad 3.54727 \mathrm{E}+11 \quad 8.24201 \mathrm{E}+11 \quad 8.33444 \mathrm{E}+11$ $8.51846 \mathrm{E}+119.54553 \mathrm{E}+11 \quad 1.04123 \mathrm{E}+12 \quad 5.36854 \mathrm{E}+11 \quad 5.95681 \mathrm{E}+11$ $1.26151 \mathrm{E}+12 \quad 1.42038 \mathrm{E}+12 \quad 1.55013 \mathrm{E}+12 \quad 1.74155 \mathrm{E}+12 \quad 9.09198 \mathrm{E}+11$ $1.02611 \mathrm{E}+121.10398 \mathrm{E}+12 \quad 1.27499 \mathrm{E}+12 \quad 1.50974 \mathrm{E}+12 \quad 1.68076 \mathrm{E}+12$ $2.20298 \mathrm{E}+122.90762 \mathrm{E}+12 \quad 4.49185 \mathrm{E}+12 \quad 7.78343 \mathrm{E}+12 \quad 1.46402 \mathrm{E}+13$ $2.75673 \mathrm{E}+13 \quad 1.73711 \mathrm{E}+13 \quad 2.19944 \mathrm{E}+13 \quad 2.80448 \mathrm{E}+13 \quad 3.50640 \mathrm{E}+13$ $4.29582 \mathrm{E}+13 \quad 5.05308 \mathrm{E}+13 \quad 5.65630 \mathrm{E}+13 \quad 2.69123 \mathrm{E}+13 \quad 7.77059 \mathrm{E}+13$ $8.55019 \mathrm{E}+126.67089 \mathrm{E}+12 \quad 1.89522 \mathrm{E}+12 \quad 1.69238 \mathrm{E}+12 \quad 7.23435 \mathrm{E}+11$ $4.29661 \mathrm{E}+113.21261 \mathrm{E}+11 \quad 2.12981 \mathrm{E}+11 \quad 1.28844 \mathrm{E}+11 \quad 1.47609 \mathrm{E}+11$ $5.34235 \mathrm{E}+104.12570 \mathrm{E}+101.42609 \mathrm{E}+09$ e t

done

end

$=$ origen

solver $\{$ type $=$ cram $\}$ options $\{$ print_xs=yes

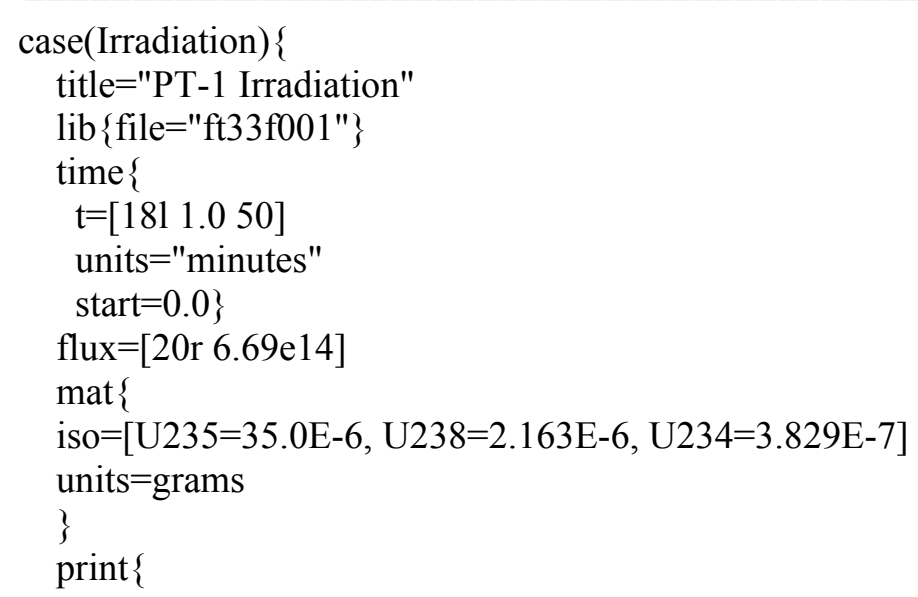

D-2 


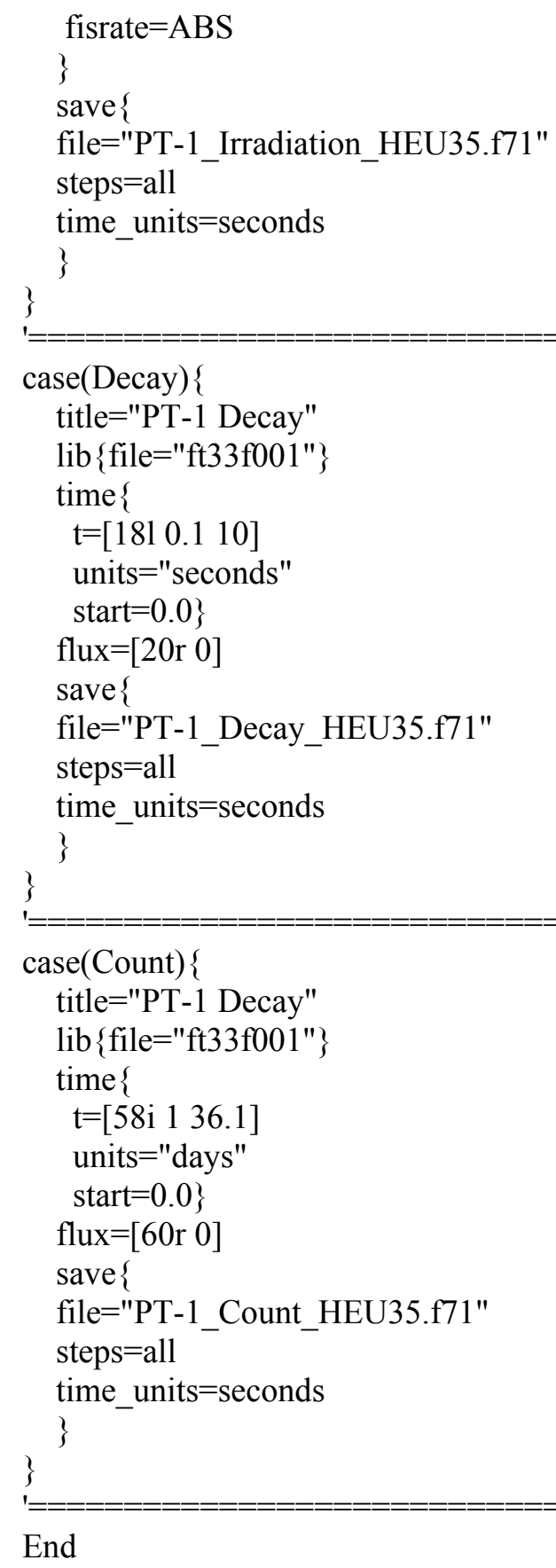

End 


\section{APPENDIX D.2-ORIGEN CALCULATED FISSION ISOTOPE MASSES FOR 35MG TARGET}

WITH 36.1 D DECAY

\begin{tabular}{|c|c|c|c|c|c|}
\hline Isotope & Mass & Isotope & Mass & Isotope & Mass \\
\hline U-235 & 3.50E-05 & Nb-95 & $1.43 \mathrm{E}-10$ & Se-78 & $1.68 \mathrm{E}-12$ \\
\hline U-238 & $2.16 \mathrm{E}-06$ & Ba-140 & $1.25 \mathrm{E}-10$ & Cd-113 & $1.62 \mathrm{E}-12$ \\
\hline U-234 & 3.83E-07 & Pd-105 & $1.04 \mathrm{E}-10$ & $\mathrm{Cd}-116$ & $1.57 \mathrm{E}-12$ \\
\hline U-236 & 4.24E-09 & $\mathrm{Nd}-150$ & $1.00 \mathrm{E}-10$ & Sn-120 & $1.55 \mathrm{E}-12$ \\
\hline Xe-134 & $1.08 \mathrm{E}-09$ & $\mathrm{Rb}-85$ & 8.99E-11 & Sn-117 & $1.53 \mathrm{E}-12$ \\
\hline Вa-138 & $9.56 \mathrm{E}-10$ & $\mathrm{Kr}-84$ & $8.62 \mathrm{E}-11$ & Sn-119 & $1.52 \mathrm{E}-12$ \\
\hline Xe-136 & $9.16 \mathrm{E}-10$ & $\mathrm{Nd}-144$ & $6.83 \mathrm{E}-11$ & Sb-121 & $1.50 \mathrm{E}-12$ \\
\hline La-139 & $9.13 \mathrm{E}-10$ & $\mathrm{I}-129$ & $6.63 \mathrm{E}-11$ & Cd-112 & $1.50 \mathrm{E}-12$ \\
\hline Cs-133 & $9.03 \mathrm{E}-10$ & Sm-151 & $6.47 \mathrm{E}-11$ & Cd-114 & $1.39 \mathrm{E}-12$ \\
\hline Cs-137 & 8.67E-10 & Mo-95 & $6.17 \mathrm{E}-11$ & Sn-118 & $1.37 \mathrm{E}-12$ \\
\hline Cs-135 & $8.65 \mathrm{E}-10$ & Te-128 & $4.58 \mathrm{E}-11$ & $\ln -115$ & $1.37 \mathrm{E}-12$ \\
\hline Ce-142 & $8.51 \mathrm{E}-10$ & $\mathrm{Kr}-83$ & $4.55 \mathrm{E}-11$ & Zr-90 & $1.13 \mathrm{E}-12$ \\
\hline Ce-140 & $7.48 \mathrm{E}-10$ & Sm-152 & $4.16 \mathrm{E}-11$ & Xe-131m & $1.01 \mathrm{E}-12$ \\
\hline Ce-144 & $7.44 \mathrm{E}-10$ & Ru-106 & $4.08 \mathrm{E}-11$ & Se-78 & $1.68 \mathrm{E}-12$ \\
\hline $\mathrm{Nd}-143$ & $7.21 \mathrm{E}-10$ & $\mathrm{Nd}-147$ & $3.46 \mathrm{E}-11$ & Cd-113 & $1.62 \mathrm{E}-12$ \\
\hline Mo-100 & $6.45 \mathrm{E}-10$ & Pu-239 & $2.82 \mathrm{E}-11$ & Cd-116 & 1.57E-12 \\
\hline Zr-96 & $6.24 \mathrm{E}-10$ & Se-82 & $2.73 \mathrm{E}-11$ & & \\
\hline Zr-94 & $6.23 \mathrm{E}-10$ & Eu-153 & $2.48 \mathrm{E}-11$ & & \\
\hline Tc-99 & $6.19 \mathrm{E}-10$ & $\mathrm{Kr}-85$ & $2.46 \mathrm{E}-11$ & & \\
\hline Zr-93 & 6.04E-10 & La-140 & $1.90 \mathrm{E}-11$ & & \\
\hline Mo-97 & $5.95 \mathrm{E}-10$ & $\mathrm{I}-131$ & $1.77 \mathrm{E}-11$ & & \\
\hline $\mathrm{Nd}-145$ & $5.84 \mathrm{E}-10$ & $\mathrm{I}-127$ & $1.76 \mathrm{E}-11$ & & \\
\hline Xe-132 & $5.83 \mathrm{E}-10$ & $\mathrm{Br}-81$ & $1.69 \mathrm{E}-11$ & & \\
\hline Mo-98 & $5.81 \mathrm{E}-10$ & Pd-107 & $1.60 \mathrm{E}-11$ & & \\
\hline Zr-92 & 5.67E-10 & Sm-154 & $1.18 \mathrm{E}-11$ & & \\
\hline Ru-101 & 5.35E-10 & Se- 80 & $1.06 \mathrm{E}-11$ & & \\
\hline Sr-90 & $5.32 \mathrm{E}-10$ & Xe-133 & $9.46 \mathrm{E}-12$ & & \\
\hline Pr-141 & $4.51 \mathrm{E}-10$ & Sn-126 & $7.25 \mathrm{E}-12$ & & \\
\hline Ru-102 & $4.49 \mathrm{E}-10$ & Pd-108 & 5.99E-12 & & \\
\hline $\mathrm{Nd}-146$ & $4.48 \mathrm{E}-10$ & Te-129m & $5.72 \mathrm{E}-12$ & & \\
\hline Zr-95 & $4.28 \mathrm{E}-10$ & Sm-147 & $5.30 \mathrm{E}-12$ & & \\
\hline Ce-141 & 3.93E-10 & Eu-155 & $5.03 \mathrm{E}-12$ & & \\
\hline Xe-131 & $3.69 \mathrm{E}-10$ & Sb-125 & $4.12 \mathrm{E}-12$ & & \\
\hline $\mathrm{Y}-91$ & 3.57E-10 & Se-79 & $3.62 \mathrm{E}-12$ & & \\
\hline Sr-88 & $3.22 \mathrm{E}-10$ & Ag-109 & $3.48 \mathrm{E}-12$ & & \\
\hline Pm-147 & $2.98 \mathrm{E}-10$ & Sn-124 & $3.40 \mathrm{E}-12$ & & \\
\hline Sr-89 & $2.64 \mathrm{E}-10$ & $\mathrm{Pd}-110$ & $2.87 \mathrm{E}-12$ & & \\
\hline $\mathrm{Nd}-148$ & $2.54 \mathrm{E}-10$ & Pd-106 & $2.86 \mathrm{E}-12$ & & \\
\hline Te-130 & $2.41 \mathrm{E}-10$ & Te-127m & $2.76 \mathrm{E}-12$ & & \\
\hline $\mathrm{Rb}-87$ & $2.28 \mathrm{E}-10$ & Ba-137 & $2.00 \mathrm{E}-12$ & & \\
\hline Ru-104 & $2.00 \mathrm{E}-10$ & Sn-122 & $1.94 \mathrm{E}-12$ & & \\
\hline Zr-91 & $1.86 \mathrm{E}-10$ & $C d-111$ & $1.92 \mathrm{E}-12$ & & \\
\hline $\mathrm{Kr}-86$ & $1.73 \mathrm{E}-10$ & Gd-156 & $1.91 \mathrm{E}-12$ & & \\
\hline Ru-103 & $1.69 \mathrm{E}-10$ & Sb-123 & $1.87 \mathrm{E}-12$ & & \\
\hline
\end{tabular}

